\title{
TÜRK KÜLTÜRÜNDE GELENEKSEL ŞAMANDAN NEO-ŞAMANA
}

\author{
Prof. Dr. Fuzuli BAYAT*
}

Öz: XX. yüzyılın sonlarında Batı'da ve Sibirya'da, Amerika'da ve Afrika'da çeşitli düzeylerde ve farklı versiyonlarda temsil edilen uluslararası Neo-şamanlık adı ile bilinen bir fenomen ortaya çıktı ancak şamanlık geleneği olmayan halklarda ortaya çıkan bu Neo-şamanlık gerçeği, şaman geleneğinden tam kopmamış Sibirya Türklerinin modern şamanlığından farklı bir boyut sergiliyor. Onları birleştiren tek nokta yeni şamanların eğitimli, farklı mistik akımları, büyüleri ve özellikle de şamanlık geleneğini iyi öğrenen insanlar olmasıdır. Neo-şamanların çoğu psikoloji, nöroloji vb. alanlarda yetişmiş bilim adamlarıdır ayrıca antropoloji ve sosyoloji uzmanlarıdır. Neo-şamanizm yeni bir biçimlenmedir, eski tasavvurların ve ritüellerin yeni bir yorumudur.

Modern Türk şamanları genelde ruhlar tarafından "seçildikleri", şamanlık görevine "çağrıldıkları" için geleneksel şamanlığı canlandırmaları ile bilinirler. Bunun dışında kalan şamanlık uygulamaları ise farklı bir Neo-şamanlıktır. Bu türden şamanlar, hem Türk neo-şamanlığına ait şaman sırlarını, kamlık ritüellerini, trans hâllerini topluma açmakla yeni bir dönem başlatmış oldular hem de şaman derneklerinde, tedavi merkezlerinde birleşerek örgütlenmiş oldular.

Türk neo-şamanları; fiziksel ve ruhsal hastalıkları iyileștirenler; toplumsal ritüelleri gerçekleştirenler; geleceği görenler, davulsuz kamlık yapanlar şeklinde kategorilere ayrılırlar. Dinlere, inançlara saygılı davranan Türk neo-şamanları tıpkı ecdatları gibi her zaman yeniliğe açıktırlar. Buna örnek olarak şaman-lama, şaman-papaz, şaman-molla ilişkilerini gösterebiliriz. Özetle modern çağın Türk Neo-şamanlığı hem felsefesi, hem ritüeli hem de aksesuarları ile modifikasyona uğramış bir şamanlıktır.

Anahtar Kelimeler: geleneksel şaman, neo-şaman, Sibirya Türk modern şamanları, şamanlığı canlandırmak

FROM TRADITIONAL SHAMAN TO NEO-SHAMAN IN TURKISH CULTURE

Abstract: In the late twentieth century, a phenomenon known as international neo-shamanism emerged, represented in the West and Siberia, in America and Africa in various planes and in different versions. However, neo-shamanism, which emerged in peoples without a shamanic tradition, exhibits a different dimension from the modern shamanism of the Siberian Turks, who are not completely detached from the shamanic tradition. The only point that unites them is that the new shamans have well-educated, different mystical currents, witches, and especially people who are well versed in the future of shamanism. Most of the neo-shamans are scholars trained in the fields of psychology and neurology, as well as anthropological and sociological experts.

\footnotetext{
ORCID ID : :0000-0002-0811-5852

DOI $\quad: 10.31126 /$ akrajournal.835988

Geliş tarihi : 05 Aralık 2020 / Kabul tarihi: 30 Aralık 2020

*Azerbaycan Millî İlimler Akademisi Folklor Enstitüsü Bölüm Başkanı.
} 
Neo-shamanism is a new format, a new interpretation of old ideas and rituals.

Modern Turkish shamans are generally known for reviving traditional shamanism because they are "chosen" by spirits and "called" to the task of shamanism. This is a different neo-shamanism. Turkish neo-shamanism has started a new era by revealing shamanic secrets, kamlik rituals and trance states to the public. They were also organized in shaman associations and treatment centers.

Turkish neo-shamans fall into several categories, such as those who heal physical and mental illnesses; those who perform social rituals; those who see the future, those who lack drums, etc. consists of. Turkish neo-shamans, who respect religions and beliefs, are always open to innovation, just like their ancestors. Examples of this are shaman-lama, shaman-papaz, shaman mullah relations. In short, modern Turkish neo-shamanism is a shamanism that has been modified with both philosophy and rituals and accessories.

Key Words: traditional shaman, neo-shaman, Siberian Turkish modern shamans, revive shamanism

\section{Giriş}

XX. yüzyılın sonları ile XXI. yüzyılda ilmi literatürde Neo-şamanlık, deneysel Şamanlık, temel Şamanlık, Post Şamanlık adları ile bilinen yeni bir olgu çıktı. Oldukça farklı biçimlenme ile oluşan bu yeni Şamanlık olgusu, medeni dünyanın büyük bir kısmını etkisi altına aldı. Yeni Şamanlık, geleneksel kültürlerinde Şamanlık olan, ancak objektif ve sübjektif sebeplerden dolayı Şamanlığın yok olduğu veya yok olmakta olduğu kültürlerde ortaya çıktığ gibi, Şamanlıkla hiçbir bağlantısı olmayan veya bağlantısı kalmayan halklarda da görülmeye başlandı. Birincisi, özellikle Türk, Buryat, Moğol, Kızılderili, Afrika ve Avustralya yerlileri arasından çıkan ve kendi kültürel değerlerini ihya etmeye çaba gösterenler, ikinciler ise son dönemlere kadar Şamanlık geleneğini yaşatan halklardan şaman tekniklerini, metotlarını, ritüellerini öğrenmekle şaman olanlardır. Bu ise diğer halkların geleneksel Şamanlığının orijinal biçimlerinden, şaman tekniklerini ve metotlarını kullanmakla ortaya çıkan Neo-şamanlıktır. Neo-şamanlık artık uygarlığın bir parçası hâline gelmiş küresel bir kültür fenomenidir.

Modern Şamanlık Batı'da ve Sibirya'da, Amerika'da ve Afrika'da çeşitli düzeylerde ve farklı versiyonlarda temsil edilen uluslararası bir fenomen hâline gelmiştir. Yeni Çağ' $n$ kendisi olan Neo-şamanlık genel olarak psikolojik ve psikoterapötik çalışma yöntemlerini bir dizi Şamanik metotlarla birleştirmekle iyileştirmekte, fala bakma, kehanette bulunma, manevi bunalımı ve fiziki ağrıları gidermeye çalışan, aidiyeti bakımından farklı kültüre sahip insanları birleştiren bir fenomen olup iki etmenle birbirine bağlıdır.

Birincisi eğitimli, farklı mistik akınları, büyüleri ve özellikle de Şamanlığı öğrenen antropolog, yazar, psikolog, tıp doktoru vs. insanların kendilerini şaman olarak adlandırması.

İkincisi, istisnasız olarak bu insanların hepsinin, ruhlar tarafından vergi olarak verilen Şamanlığı bir öğretmen, bir usta konumunda olan şamanın kıla- 
vuzluğunda kitaplardan ve deneyimlerden öğrenenlerdir. Oysa geleneksel şamanların kanısına göre Şamanlık öğrenilmez verilir, şaman olunmaz, şaman doğulur. Doğal olarak neo-şamanları şartlı olarak bin yılların geleneğini bozup, yeni gelenek yaratanlar olarak adlandırmak doğru olacaktır.

Neo-şamanlığın ortaya çıktı̆̆ı XX. yüzyılın sonları ile XXI. yüzyılı "küreselleşme", "dijitalleşme", "bilimsel ve teknolojik ilerleme", "yüksek teknolojiler çağı", "elektronik çağ", "nanoteknoloji asrı" terimleriyle karakterize etmek mümkündür. Bu olumlu olanlar ne yazık ki kendisiyle beraber olumsuz tanımlamaları örneğin "dünya görüşü gerilemesi", "arkaikleştirme", "erime, yok olma", "ahlaki dejenerasyon", "millî-manevi değerlerin yıpranması" vs. adı verilen süreçlerin başladığı gerçeğini de ortaya çıkarmıştır.

Neo-şamanizm yeni biçimlenmedir, eski tasavvurların ve ritüellerin yeni bir yorumudur. Neo-şamanizm New-Age ${ }^{1}$ (Yeni Çağ) hareketinin bir çıkış, kurtuluş kodudur. Burada Neo-şamanlığın postmodern kültürün açıklayıcı bir fenomeni olduğunu ve post-endüstriyel uygarlığın koşulları ve teknolojileri ile belirli bir simbiyoza ${ }^{2}$ giren arkaik dinî inançlar ve kültlerden bir şeyler alarak ortaya çıktığını da hatırlatmak gerekir.

1. New Age (Yeni Çağ) - senkretik yapıya sahip bir grup gizli hareket olup, ruhsal konulara ilişkin bireysel eklektik yaklaşımla nitelendirilen çağdaş Batı Kültüründe yirminci yüzyıl sonlarında ortaya çıkan ve sınırları ve alt gruplarıyla geniş bir uygulama ve inanç alanına işaret eden ve alternatif ruhsal hareketlerin üst başlı̆̆ ve türsel bir terimdir. Herhangi bir değişmez, mutlak kutsal metin, dinî kurum ve din adamları hiyerarşisinden uzak olduğundan din sosyolojisinde New Age'in geleneksel din ile arasındaki farkı ortaya koymak için akademik literatürde New Age'e, yarı dinî veya dinleyici/izleyici kültü ve kült çevresi/ortamı şeklinde tanımlar getirilmiştir.

Yeni Çağ hareketinin XX. yüzyılın sonunda en az 100 milyon taraftarı (yarısından fazlası Amerika Birleşik Devletleri'nde yaşıyor; Rusya'da, çok doğru olmayan tahminlere göre yaklaşık 1 milyon) olduğu varsayılır. Ana eğilimler, İkinci Dünya Savaşı'ndan sonra teosofi temelinde oluşturuldu. Şimdi en az 5 bin farklı hareketi ve mezhebi birleştiriyor; bunların başlıcaları Teosofi, Antroposofi, Swedenborgianizm, Spiritüalizm, Liberal Katoliklik, Agni Yoga, Ben'im, Yeni Akropolis, Üniversalizm'dir. New Age, özellikle şifa üzerinde durur. İnsanın içinde onun fiziksel ve psikolojik sorunlarının üstesinden gelmesini sağlayan kozmik bir güç vardır. Aynı güç evrende çeşitli güç merkezlerinden de enerji hatları yayılmaktadır. İnsanların bilinçlerinde gelişmeyle içlerindeki bu gücün farkına varacaklar, böylelikle herhangi bir dışsal otoriteye (dinî kurum, hiyerarşi, rehber vs.) ihtiyaç duymadan bu güçlerini kullanacaklardır.

2. Simbiyoz veya ortak yaşarlık, iki canlının tek bir organizma gibi birbirleriyle yardımlaşarak bir arada yaşamaları. Simbiyoz veya simbiyozis, "ortak yaşama" anlamındadır. Birden fazla canlı türünün, belirli koşullar altında bir arada yaşaması, simbiyozis olarak tanımlanır. Simbiyoz, genel olarak canlılar arası bir ilişki türü olmakla birlikte, bu ilişkiye katılan (ortak olan) tüm canlıların fayda görmesi sonucu oluşur. "Simbiyoz" kelimesi genellikle, iki veya daha fazla türün karşılıklı fayda durumunda olduğu; madde, enerji veya bilgi alışverişinin olduğu doğadaki ilişkisiyle ilişkilendirilir. Endüstriyel simbiyoz, şirketlerin bir arada endüstriyel işbirliği içinde olduğu, birinin atığının diğeri için hammadde olduğu bir aracılık yapısıdır. 


\section{2. Şaman Araştırmaları veya Neo-Şamanlığın Temel Bileşenleri}

Altaylılar kendi neo-şamanlarını modern zamanda sadece "bilgili insanlar" olarak adlandırırlar. Bu kategori kendi arasında "görenler", "duyanlar", "şifacılar", "gelecekten haber verenler" ve "koruyucular" adı altında daha küçük gruplara ayrılır ki her birinin kendine özgü toplumsal işlevi ve rolü, yeteneği ve yeri vardır. Eski zamanlarda bütün bu sadalanan kategorileri tek başına geleneksel şaman yerine getirirdi. Türk şamanı "Öteki dünya olarak betimlenen ruhların veya gözle görülmeyen varlıkların dilini bilen, dolayısıyla iletişim sağlamak için tercümanlık yapan ve bin yıllarca biriken ve zamanla unutulmağa yüz tutan kozmik hafizada saklı olan gizli bilgileri topluma üstü kapalı simgelerle ötüren bir ruh bilicisidir. O hâlde şaman; öteki dünyanın bu dünyadaki temsilcisi, unutulan gizli bilgilerin kaynağıdır, kutsal bilgileri veya karşılıklı istekleri (ruhların insanlardan, insanların da ruhlardan istediklerini) ileten ara bulucudur.

Şamanın esas fonksiyonu görmek $\rightarrow$ anlamak $\rightarrow$ iletmektir. Bu üçlü fonksiyonu gerçekleştiren şaman, toplumun özel statüye sahip bireyidir. Hem de şaman yalnız toplumun fiziki sağlığı için değil, aynı zamanda manevi dünyası için de mesuldür (Bayat, 2006: 22-23). Geleneksel şamanın görevi insanları ve hayvanları iyileştirmekten, kayıp eşyaları bulmağa, ölen birisinin ruhunu öteki dünyaya yola salmaktan kurban sunmaya, temizlik ritüeli yapmaktan avın bol olmasını sağlamaya, kısırlığı gidermeye kadar geniş bir alanı kapsamaktadır. Bu kadar çok kamusal görev üstlenmiş şamanlar kendi aralarında bir hiyerarşiye tabidirler.

Nitekim Kumandin şamanı Makar Vaslyeviç Kastarakov ilk önce şamanların hiyerarşisinden bahseder, onları büyük şaman (Uluh kam) ve küçük şaman (Irbıkçi kam), orta şaman (Orto Kam) ve yeni başlayan şamana (Kiçi Kam) ayırır. Sonra Kastarakov, "gizli uygulama ve becerilere bağlı" uzun bir listeden alıntı yapıyor: Irımçi-talgah (nöbet ve eziyetlerle geleceği gören, öngören) ve falcılardan masaj terapistlerine ve kiropraktörlere kadar bir bölgü yapıyor. Başka bir Telengit şamanı O. K. Askanakov "bilgili insanlar" hiyerarşisine ilişkin görüşlerini anlatarak onları iki büyük gruba ayırıyor: kam ve yarlıkçı. Bir şaman gibi Askanakov, yarlıkçı kelimesini farklı bir şekilde kullanarak "Beyaz inanç" (Ak yang) hakkında kendi yorumunu veriyor. Askanakov'a göre, yarlıkçllık kategorisi, davulu olmadan çalışan ve çoğu zaman, yeteneklerini ve becerilerini kalıtsal olarak değil, eğitim yoluyla elde eden tüm bilgili insanları kapsar. O. K. Askanakov, hiyerarşisinin en alt seviyelerine yetenekleriyle ruhlarla ilişkilendirilen, şarkılar söyleyen (kojongçı), masal anlatan (çörçokçi) ve şairleri yerleştirir. Ardından, ruhları ve ölüleri açıkça "gören", ancak gördüklerini etkileyemeyen kösmçökçi gelir. Öğrenimini geliştirdikten 
sonra, kösmçökçi daha yüksek seviyelere yükselebilir, örneğin bir kürek kemiği veya artış ardıçı ile fala bakabilir. Tüm şamanlar bir tür profesyonel temel olarak kösmçökçinin yeteneklerine sahiptir. Buraya kösmçökçi ve yarınçılardan (fala bakanlar) daha üst yerde yerleşen ve faaliyetleri daha önemli olan geleneksel halk şifacıları (emçiler) da dahildir. Daha üstte davulsuz şaman, yani yarlıkçı vardır ki eğer ruhlar ona bu konuda yardım ederse sonraki en yüksek seviyeye yükselebilir (Доронин, 2013: 91-92).

Buna rağmen Uzak Kuzey halklarında durum farklıdır. Nitekim bu halkların arasında herhangi birinin şaman olabilme yeteneğine sahip olduğuna inanılır. Bunun için sadece kendini şaman ilan etmek yeterlidir. Şaman unvanı nihayet, yeni şamanın faaliyetinin gerçek sonuçlarına dayanarak toplumdaki insanlar tarafından pekiştirilir. Ancak her ne olursa olsun ister soyla geçen şamanlık olsun, isterse de kendini şaman ilan etmekle şaman olunsun, fark etmez, kimin şaman olup olmayacağına karar vermek hakkı yine de ruhlara bırakılmıştır. Çünkü adaya gerçek şaman gücünü sadece ruhlar verebilir. Türk şaman memoratlarını, Çukçi, Kamçatka şaman efsaneleriyle kıyasladıkta da bunu rahatlıkla görmek mümkündür. $\mathrm{O}$ nedenle Türk toplumunda kendi isteğiyle şaman olmanın neredeyse imkânsız olduğunu şaman efsane ve memoratları da kanitliyor:

"Bundan iki yll önce bir yaz mevsiminde Byurtyuntsah'da bir adam yakında şaman olacağını bildirdi ve kendine ormanda bir ev yapılmasını söyledi. Ev çok büyük bir ağacın üstüne kuruldu. Bu ağaç, şamanların kamlık ettikten sonra oraya bıraktıkları küçük heykelciklerle dolu idi. Bu evi evlenmemiş bekar gençler yapmalıydı. Şaman olmak isteyen kırk yaşlarındaki bu adamın adı Mikail Savviç Nikitin'di. O ev bitince oraya gitti ve üç gün boyunca yeni evinde uzandl. Mikail Nikitin kendi kendine:

- Ben ölü gibi yatıp, parçalanmaya maruz kalırım, üçüncü gün ben dirilmeliyim, derdi.

Üçüncü gün için o meşhur şaman Taapp' In oğlu Şaman Böçyukee'yi, şamanın kaldırılması veya eğitim merasiminin yapılması için davet etmişti... Davetli şaman gelince evin etrafina bu merasimi seyretmek için insanlar toplandl. Ben de bu merasimi izlemek için oraya gittim.

Davet edilen şamanin elinde davulu vardl. Şaman olmak isteyen Mikail Nikitin ise yalnı şaman cübbesi giymişti. Merasimi yönetecek şaman, yardımcı ruhlarını överek ve onlarla istişare yaparak:

- Şimdi yazın ortasındayız. Otların tam yeşerdiği, ağaçların yapraklarının yeterince büyüdüğü bir aydır, bu yüzden de şamanı kaldırma merasimi yapmak bu ayda olmaz. Kaldırma merasimi ancak ilkbaharda ve sonbaharda yapılır, dedi. Bunu söyledikten sonra o kamlık yapmayı bıraktı. Şaman olmak isteyen 
Mikail Nikitin, bugüne kadar gerekli şekilde kamlık yapamıyor. O yalnız davulsuz, tokmaksız, kendine çektiği küçük ruhların aracıllğıyla dualar eder ve önemsiz hastalıklarl iyileştirir. O hâlen şaman olma süreci içindedir." (Ксенофонтов, 1930: 42-43).

Kısaca değinmiş olursak, şaman olmada adayın töslerle (ruhlar) yakın iletişimi esastır. Ruhlar tarafından seçilmiş aday, acılı, ağrılı bir hâl yaşar ki buna Altaylılar, Teleütler "tös/töz pasyat", Hakaslar "hamnı tözi pasça" (şamanı kendi tosü ezer) derler. Güney Sibirya şamanlığının en iyi araştırmacılarından biri olan N.P.Dırenkova'ya göre şaman hizmetine çağrı, Teleütler arasında ruhun zorlaması anlamına gelen "tös pasçat" (ruh ezir) terimi ile yorumlanan özel bir "şaman hastalı̆̆ı" saldırısıyla ortaya çıkar. Bu dönemde şamana "paskin kam", yani “zorlanmış, ezilmiş şaman" derler (Дыренкова, 1949: 109). Şaman efsane ve memoratlarında hastalıkla bağlı çok sayıda anlatılar vardır:

"Şaman adaylarl dokuz, bazllarl ise yedi yaşından itibaren sinir hastallğına tutulurlar. Bu ruhi hastalık üç yıldan yedi yıla kadar devam eder. Bazılarinda hastalık krizlerle, nöbetlerle, bayllmalarla ve klsa aralıklı kendine gelmelerle devam eder.

Bu sirada onlar her türlü mundarlıktan, kötülükten çekinmeli, zamanları dolana kadar kamllk etmemelidirler. Bu zaman içinde gelecek şamanların gözlerinin açıldığını, dualar söylediklerini ve gelecekten haber verme gibi yeteneklerinin oluştuğunu söylerler." (Bayat, 2019: 108).

Şaman hastalığı ölen şamanın kendi soyundan birinin içine girmesi gibi anlaşılır. Adaya azap veren de onun ağzıyla şarkılar söyleyen de ölmüş şaman akrabasının ruhudur.

Türk geleneksel Şamanlığının ritüelleri, kamlık sistemi, şaman vergisi, şaman hastalığı, şaman giyim-kuşamı iyi araştırılmıştır (Вербицкий, 1893; Анохин, 1924; Трощанский, 1903; Ксенофонтов, 1992; Дыренкова, 1930: 261-291; Дыренкова, 1949: 108-190; Попов, 1947: 282-293; Попов, 2008; Иванов, 1954; Потапов, 1991; Алексеев, 1975; Алексеев, 1984; Басилов, 1992; Кении-Лопсан, 1987; Кенин-Лопсан, 1999; Сатлаев, 1974; Бутанаев, 2006; Новик, 1984; Сагалаев, 1984; Функ, 1997; Шаманизм народов Сибири, 2006; Баскаков, 1973: 108-113; Вайнштейн, 1961). Özellikle XIX. Yüzyılın başlarından zorla Hristiyanlaştırılan Altay ve Yakutların Sovyetler Birliği'ne kadarki geleneksel kültürün üst köşesinde yer alan, millî dünya görüşün özü olan Şamanlık antropolog, etnolog, folklorist ve din tarihçilerinin araştırma objesi olmuştur.

Geleneksel Şamanlık özel bir yetenektir, farklı bir algı, farklı bir ruh hâlidir. O nedenle şamanların durumu sinirbilim tarafından büyük ilgi görmektedir. Nitekim bir taraftan transa grime, diğer taraftan trans hâlinde de kendini kontrol etme becerisi nadiren görülen yetenektir ki bunu şamanlarda görürüz. 
Başka bir bilinç seviyesine ulaşmak için, beynin bazı fonksiyonlarını engelleyebilmek ve duyularını yönlendirebilmek için şamanlar birtakım özel uygulamalar kullanmaktadırlar, ki bunların başında psikoaktif maddeler içeren bitki ve mantarların kullanılması, arakı denilen alköllü içecekler ve mestedici tütünlerden yapılan sigaraların içilmesi, davulun düşük frekanslı seslerinden ve boğaz şarkılarından, hırıltılardan istifade, şaman dansı adlandırılan keskin ritmik hareketler, zıplamalar, şamanın özel giysilerini, başlığını süsleyen metal levhaların ve saçakların titreşimlerinden vs. yararlanmak gelir. Ayrıca klasik bir şaman, sıradan bir insanı kolaylıkla transa sokabilir ki insan bunun farkında olmayabilir. Bunun üzerinde bir kişinin bilincinin ruhlar dünyasıyla temasa geçmesi, yani sözde sihirli hipnoz süreci de uygulamalar arasındadır. O nedenle kamlık seansına katılanların gözünde şaman kolaylıkla bir veya birkaç hayvana dönüşebilir. Ritüele katılanlar, şamanın nasıl kurda, ayıya veya kuşa dönüştüğünü görüyorlar, hatta koku alıyor ve sesleri duyuyorlar. Burada ilginç olan, seansa sonradan katılanın, şamanı her zamanki hâliyle gördüğünü söylemesidir.

Aslında "şaman, kendine has bir icraata ve bu icraatı gerçekleştirmek için özel tekniklere sahip (trans hâlleri, oyunculuk, iluziyon vs.) olan ve belli merasimleri yapan, genelde kötü ruhlar diye nitelendirilen varlıklara hüküm edebilen aracıdır. $O$, insan psikolojisini iyi bilen, korku ve inamın, saygı ve sevincin kaynağı üzerinde bir uzman gibi serbest davranan kişiliğe sahiptir. Din adamlarından (kahin, rahip, keşiş, molla, lama) farklı olarak şamanlar, esrime (extase) tekniğinden istifade ederek ruhlarla samimi bir ilişkiye girerler." (Bayat, 2006: 25).

Sibirya Türk neo-şamanları da selefleri gibi bu özel şaman uygulamalarından yararlanmaktadırlar. En azından eski şamanlar gibi transa geçmeseler de bütün bu aksesuarların varlığı onların şamanlık konusunda ne kadar deneyimli olduklarını kanıtlıyor. Ancak neo-şamanın giysisi, davulu, tokmağı, başlığı klasik şamanınkinden farklı olarak herhangi bir koruyucu ecdat ruhunun talimatı ile yapılmaz. Bu giysi, davul ve diğer aksesuarlar rastgeledir ve neo-şamanın fantezisine, bireysel düşüncesine bağlı şekilde yapılır. Bununla beraber neo-şaman da belli bir eğitim sürecinden geçmiştir. Çünkü gerekli eğitimden geçmeyen, hazırlığ olmayan birinin zor ve tehlikeli ruhsal çalışma olan Şamanlığa soyunması kötü sonuçlar doğurabilir. Genel olarak Sibirya halkları etnik terkibine bakmaksızın geleneği inşa etmek veya geleneksel Şamanlık üzerinde Neo-şamanlık denilen yeni şamanlık kurmak eğilimindedirler.

Şamanlıkta özel olarak yapılan mabet, tapınak yoktur, taşlar, ormanlar ve nehirler arasında açık havada kamlık yapmak, tapınağın, doğanın ta kendisi olduğunu kanıtlıyor. Burada son dönemlerde Buryat şamanlarının mabet yap- 
mak için girişimde bulunmaları, bunu Japon, Kore Şamanlığında tapınak olduğu düşüncesine dayatarak geliştirmek çabalarını da belirtmek gerekir. 2013 'den başlayan, 800 adamın yerleşebileceği, uzunluğu $8 \mathrm{~m}$ ve 8 köşeli "Gök Mabedi" (Tengeri ordon) adlanan şaman mabedinin inşası tamamlanarak 26 Mayıs 2020'de açıldı (https://nazaccent.ru/content/29870-pervyj-v-rossii-shamanskij-hram-otkroetsya.html; https://ulan-ude.sm.news/pervyj-v-rossii-shamanskij-xram-chto-eto-znachit-4704/). Budizmin ilkel varyant1 olan mabet yapmak şamanlığı duvarlar arasına hapsetmektir. O bakımdan Sibirya Türk şamanları, hatta Batı neo-şamanları da bu fenomeni mabet veya tapınağa habis etmek istemiyorlar. Geleneksel Şamanlığı inşa etmeye çalışan Altaylı ve Yakutyalı kent neo-şamanları icraatlarını belli bir yerde, odada, tedavi merkezlerinde veya kendi evlerinde yapıyorlar. Artık doğanın her köşesinin kamlık yeri olması, yerini tapınak olmasa da lokalize edilmiş kapalı mekanla değiştirmiştir. Bazı Yakut, Tuva, Hakas köylerinde doğa hâlen de tapınak görevini yerine getirir. Toplumsal karakterli ritüeller ise doğada yapılır.

Animistik düşünceyle Şamanlık arasındaki yakın ilişki Şamanlığı bir doğa kültü olarak algılamaya olanak tanır. Nitekim Şamanlık aslında animistik bir ideolojidir ki esas karakteristik teknik özelliği ekstaz durumuna girmekle geleceği görmeğe dayanır. O nedenle de Sibirya Türk şaman felsefesi tıpkı doğada olduğu gibi ölüp dirilme ideolojisine esaslanır. İki veya üç-dört defa doğulmayan şaman Türk Şamanlık inancına göre şaman değildir. Ölüp yeniden ve yeni statüde dirilen şaman aynı zamanda ölüler dünyasıyla diriler dünyası arasında bir arabulucudur, ölülerin ruhlarına öteki dünyaya kadar refakat edendir. Şamanın kaostan çıkması onun yeniden dirilmesidir ve şaman bu dünya ile öteki alem arasındaki "antlaşmayı" gerçekleştiren kişidir.

Şaman bu olağanüstü yeteneği ölüp dirilme sırasında çektiği azaplara, parçalanıp yenilmeye, iç organlarının, gözlerinin ve kulaklarının yenilenmesine borçludur. Ölüp dirilme olgusunda birtakım simgesel eylemler ve fiziksel edimler aracılığıyla, şaman adayına yeni bir yaşamda "doğmak" üzere "öldüğü" duygusunu aşılamak telkin edilir:

"Bir zamanlar iki kardeş vardl: Bunlardan biri 30, o bürü 20 yaşındaydl. Onların babalarl ve anneleri çoktan ölmüştü. Bir gün abisiyle yaşayan küçük kardeş evlendi... Aynı yılın sonbaharında küçük kardeş hastalanarak öldü. Ancak ölüm döşeğinde yatarken o, etrafinda konuşulanların, olup bitenlerin hepsini duyuyordu, ancak ne kalkabilir, ne de bir şeyler söyleyebilirdi. Onun için tabut yapıldığını ve mezar kazıldı ğını işitti. Uzanmış hâlde o kendi kendine düşünüyordu, ne var ki dirilebileceğine şansı olduğu hâlde onu gömdüler. Onu tabuta koyup, mezara gömdüler ve üstünü toprakla örttüler.

Mezarda yattı̆̆ yerde birilerinin mezarı kazdlğını duydu. Sevinçle düşündü ki bu onun abisidir. Onun ölmediğini anlayıp mezardan çıkarmağa gelmiştir. 
Sonunda tabutun kapağını açtılar. O, önceleri hiç görmediği dört siyah adam gördü. Adamlar onu kaldirtp ikiye büktüler ve bu vaziyette yüzünü evine döndürüp tabutta oturttular. Evin damindan duman çıklyor, pencereden yanan ocağın ateşi görünü-yordu. Yerin derinliklerinden boğa sesi gelmeye başladl. Boğanin böğürtüsü yavaş yavaş yaklaşlyordu. Toprak sallandlkta o çok korktu. Onun mezarından boynuzları bir birine çok yaklaşmış siyah renkli bir boğa çıktı. Boğa tabutta oturan adamı boynuzları arasina alıp geldiği delikten de geri döndü." (Bayat, 2019: 59-60).

Hatta bazı şamanların iki veya üç defa, hem de bazen cinsiyet değiştirerek doğması olayı vardır ki bu inisiyasyonunu genellikle şamanın yeniden yaranma sürecinin mikrokozmosunu temsil ettiği düşünülür. Bir Yakut şaman efsanesinde şöyle denilir:

"Inanca göre çok meşhur şamanlar üç defa doğarlar. Tarkayll şaman Aaca Oyun hakkında derler ki öldükten sonra Solong Tunguzlarının içinde Klsıltay Udagan adlı kadın şaman olarak doğmuştu. Onun, üçüncü kez doğacağını da söylerler." (Bayat, 2019: 63).

$\mathrm{Bu}$ ezoterik içerikli inisiyasyonun ölüp dirilme adlanması da ikinci veya üçüncü doğuşla ilgilidir. Bu olgu reenkarnasyon da değildir. Nitekim şaman genelde kendi vücuduyla dirilir, başka bir vücutta hayat bulamaz. Bu kural genel olarak Türk Şamanlık kurumu için daha çok geçerlidir (Bayat, 2006: 5051). Türk şamanlarının ruhlar tarafından parçalanması, dolayısıyla ritüel ölümden geçmesi bir doğa olayını yansıtır:

"Şamanların anlattıklarına göre güçlü şamanların vücudu üç kez, zayıf şamanlarınki ise bir kez parçalanmaya maruz kalır. Parçalanma sırasında, şaman ölüm kalım mücadelesi vererek cansız bir hâlde yatar. Bu esnada ruhların toplandiğını söylerler. Parçalanma sirasında şamanın başını kesip bir direğe geçirirler. Vücudunu küçük parçalara ayırıp orada bulunan ruhlara verirler. Toplananlardan hangisine ayak eti gelirse şaman ayak hastalıklarını iyileştiren güce sahip olur. Eğer ruhlardan birisi kulak etini yerse şaman kulak hastalığını iyileştirir. Etinden, toplanan ruhlardan birine veya bir kaçına gelmezse şaman o ruhlar için kamlık yapamaz. O, yalnız etini yiyen kötü ruhlarla mücadele edebilir. Yeni şamanın dünyaya gelmesine onun akrabalarının ölmesi eşlik ediyor." (Ксено-фонтов, 1930: 56-57).

Sibirya Türk Şamanlığında üç defa ölüp üç defa dirilen şamanların daha güçlü olduğu inancı vardır ki burada da şaman kendi vücudunda dirilir. Ölüp yeniden kendi vücudunda doğmak Türklerde reenkarnasyon olayının olmadığını ispat eder. Bununla beraber öldükten sonra başka halkın bireyi veya başka bir cinsin ferdi gibi doğuma hâlleri de vardır ki burada ruhun bir bedenden diğerine göçü olayıyla karşılaşırız. 
Ayrıca şaman ritüelleri, hedefe ulaşmak için şamanın geleneksel "sanal yollarını" kullanarak iyi bilinen "senaryoya" göre, ulus/toplulukta ata tanrılara ve/veya ruhlara y1llık/mevsimlik kurbanlar şeklinde gerçekleştirilir. Bu da kendi başına doğa kültünün ve ölüp yeniden dirilmenin simgesel açılımıdır. "Şamanın ölüp dirilme olarak bilinen ezoterik inisiyasyonu aslında "dışarıdaki, yabancı, bigâne ve bilgisiz" adayın "içeri" - ezoterik bir kurum olan Şamanlık dünyasına alınması, dolayısıyla şaman dünyasına mahrem kılınması, Şamanlığın hizmetçisi durumuna getirilmesi ve ezoterik bilgi ışığına kavuşmasıdır. O hâlde ölüp dirilme, şaman adayının varlığın bir alt aşamasından bir üst aşamasına geçidini ruhsal olarak gerçekleştirmesinden başka bir şey değildir (Bayat, 2006: 51).

Şamanın hem ölüp dirilmesi hem de birbirinin üzerinde olan dünyalar arasında kozmik seyahat yapabilmesi mitolojik kültürel kahramanın (medeni kahraman) işlevleriyle yapısal semantik bağlamda ayniyet oluşturur. Bu ayniyet hem yapısal hem de tematik anlamda gözlemlenir. Bu ayniyetin kökeni sosyotarihsel koşullarda ortaya çıkan olgularla ve bu olguların mitolojik anlamıyla alakalıdır. Nitekim kültürel kahraman, toplumun yararı için yukarı ve aşağı dünyalara giderek oradan gerekli nesneyi getirir. Bu işlevin masalsı varyantı özellikle halk biliminin çeşitli türlerinde yaygındır. Şamanlar da tolumun koruyucularıdır ve onların yukarı ve yer altı dünyasına seyahatleri kendi çıkarları için değil sosyal görev içindir.

\section{Yeni Bir Şamanlık Geleneği veya}

\section{Batı Neo-Şaman Kavramından Farklı Bir Yorum}

Orta Asya ve Sibirya Türklerinin yeni bir Şamanlık anlayış1 içinde olduğunu ilk müşahede edenlerden biri de N. Basilov oldu. Basilov'un, Şamanizmin yeni Neo-şamanlık formunda ortaya çıkma olasılığı hakkındaki görüşlerine göre, Şamanizmin yeni biçimlerde ortaya çıkabilmesi o kadar da şaşırtıcı değil - bu biçim geleneksel temelde değil, mistisizm tutkusu içinde kendini gösterir (Басилов, 1984: 189). Ancak daha önce de zengin şaman geleneğinden çok az şeyin kaldığını A. Anohin de müşahede etmişdir. O Sagay ve Kaçin Şamanlığı üzerinde apardığı müşahedelere dayanarak 1911 yılında şöyle yazırdı: "Ancak bir bütün olarak Şamanizm mevcut değildir. Şamanlık şimdiki durumunda zengin Şamanizmin sadece acınaklı bir kalıntısıdır." (Бутанаев, 2006: 4). Onu da vurgulamak gerekir ki bazı bilgilere göre geleneksel Şamanlık az veya çok derecede Tuva'da, Moğolistan'da korunmaktadır. Şöyle ki geleneksel şaman kültürünün çok az taşıyıcısı kalmıştır. Çarlık döneminde Hristiyanlaştırma, Sovyet döneminde zulüm ve kamplar Şamanlığı bitirmiştir. Şu anda, Şamanizm sadece Tuva'da tam olarak temsil edilmektedir ve bunun nedeni sadece bu cumhuriyetin Sovyetler Birliği'nin terkibine geç bir dönemde 
1944'de dâhil olmasıdır. Bu da onların 1930'larda şamanlara yapılan zulümden kısmen kaçabilmelerine sebep olmuştur (https://magicbom.ru/things/shamany-altaya-i-drugih-regionov-sibiri-nastoyashchie-shamany.html).

Sadece Tuva'da değil, Uzak Doğu'da geleneksel Şamanlık daha iyi korunmuştur. Şöyle ki Sovyet döneminde Habarovsk Bölgesi'ndeki Nanay şamanları hâlâ eski ritüelleri yerine getirmekteydiler. Bunu onlar toplumdan uzakda, doğanın koynunda veya evlerin perdeli pencerelerinin arkasında gerçekleştirmekteydiler (https://russian7.ru/post/za-chto-v-sssr-khoteli-unichtozhit-shamano/). Ancak şamanlar da mevcut durumun farkındadırlar. Mesela şaman Dimitriy İlin'e göre "Çarlık döneminde var olan klasik Şamanizm, Sovyet yönetimi altında öldü. Çoğunlukla şamanlar yok edildi. Hakasya'da, XX. yüzyılın sonunda, tek bir şaman bile kalmadı. Orada kabile şamanlarından bahsetmeye gerek yok. 2012'de, Atlas örgütü kaç şaman ya da şu ya da bu ölçüde Şamanist fikirlere inananları saymaya çalıştı. \% 1.5, yani doğada ruhlara inandıklarını söyleyen yaklaşık bir buçuk milyon insan vardır.

Tuva'da, Moğolistan'da, Buryatya'da, Uzak Doğu'da, Yakutya'da geleneksel Şamanlığı yaşatanlar hakkında bazı varsayımlar mevcuttur. Mesela, A.Alekseyev'in de vurguladığ 1 üzere bugün Yakutya'da, belki sadece hakiki iki veya üç şaman kalmıştır. Bunlar: Vilyuy ulusunun Jemkon köyünden Fedot İvanov, Verhoyansk ulusunun Batagay kasabasından Anna Sofroneva ve geçen yıl ölen, manevi adı Şaman Savey olan büyük şaman Semyon Stepanoviç Vasilyev'dir. Şaman Savey, İengra'dan olup Yakutların en güçlü şamanı olarak bilinirdi (https://magi-cbom.ru/things/shamany-altaya-i-drugih-regionovsibiri-nastoyashchie-shamany. html).

Hakiki şamanların varlığı hakkında bilgiler mevcut olsa da, bu hiç de gerçek klasik Şamanlık demek değildir. Çünkü ister Türk toplumunda ister Rusya'nın kuzeyinde isterse de Kızılderililerin kültüründe yaşatıldığına inanılan geleneksel şamanlık bir mit olarak mevcuttur. Başka bir deyişle klasik şaman hatta var olduğuna inanılan halklarda dahi kültürel programın bir parçası olarak mevcuttur. Oysa Neo-şamanizm geleneksel Şamanlığın katı kurallarına kayıtsız kalması nedeniyle, kişinin kendi egosunun sınırlarının ötesine geçmesine olanak tanır. Neo-şamanizm geleneksel şaman tekniklerini zamana uyarlayarak, onlara yeni anlamlar ve yorumlar katarak yeniden canlandırmıştır.

Sibirya Türk Şamanlığının canlanması/canlandırılmasının birkaç sebebi vardır ki onlardan biri de geçmiş Sovyetler Birliği'nde 1980'lerden başlayan halk hekimliğinin yeni bir ivme kazanması ile gündeme gelmesidir. İlk dönemlerde halk tabipleriyle neo-şamanların faaliyeti paralel şekilde gidiyordu. Bazı şamanlar halk tabipleri gibi faaliyet göstermek için diplomalar veya sertifikalar alır, hatta bazıları psikoloji, parapsikoloji, nöroloji alanında tez savunarak doktorluk payesi kazanıyordu. Neo-şamanların da büyük çoğunluğu tıp alanında 
eğitim görmüş, diplomalı, doktoralı insanlardı ve onlar hukuki bakımdan kayıt altına alınmış dernekler ve merkezlerde çalışıyorlar. Neo-şamanların bir kısmı üniversite hocası, bir kısmı hastanede doktor vs. gibi görevler taşıyorlar. Onların kendi saytları, Şamanlık konusunda verdikleri seminerleri var. Sibirya neo-şamanları internette kendi web sitelerini kurdular ve bu sitelerin yardımılla kendi vatanlarında, hatta dünyanın çeşitli "kutsal" bölgelerinde etnokültürel faaliyetlerini geliştirmeye başladılar. Özellikle tanınmış modern Şamanik uygulayıcılar ya doğdukları kendi topraklarında ya da başkentte ya da Rusya'nın diğer büyük şehirlerinde ya da anavatanlarının dışında şaman merkezlerinde çalışıyorlar. Ancak sade halk hekimliğinden farklı olarak neo-şamanlar pratik tedaviyle yanaşı, ruhsal bir tedavi de uyguluyorlar. Neo-şamanlar bilimsel ve çoğunluğu popüler sempozyumlara, konferanslara, toplantılara katılarak bildiri sunmaktadırlar.

Halk hekimliği o kadar geniş yayıldı ki zamanla şamanları geleneksel tıpla ilgilenen tıbbi eğitim görmüş insanlarla bir tutmaya başladılar. O nedenle de bütün Sibirya aborijenlerinin problemlerini çözmek için Kanada' da yaşayan ve çalışan Yakutyalı Aleksandra Grigoryeva "Dünya Yurdu" adlı Uluslararası Yerli Halklar Kamu Örgütünü kurdu ve kendisi de onun başkanı oldu. A.Grigoryeva şamanların kurultayında iştirak ederek geleneksel halk hekimliği konusunda bildiriler sundu.

Rus ve sonraki dönemin Sovyet araştırmacıları Şamanlığın daha çok halk hekimliği konusuna dikkat verdiklerinden Sovyetlerin çöküşünden sonra ortaya çıkan Neo-şamanlık geleneksel tıp ile ilgiliydi. Diğer tarafdan özerk cumhuriyetlerde, özellikle de Saha Cumhuriyeti (Yakutya), Tuva ve Buryat cumhuriyetleri, Şamanlığı geleneksel din olarak ilan etmekle halk şifa yöntemini şamanın en önemli işlevi hâline getirdi. O bakımdan hem geleneksel Şamanlığın hem de Neo-şamanlığın halk tababeti Şamanizmle ilişkilendirilebilecek tüm diğer uygulamaları biraz geride bıraktı ve bu nedenle ilk Şamanist örgütler hastaları iyileştirici bir yönelime sahip oldular. XX. yüzyılın 90'lı yıllarının başında aktif olarak halk tedavi ve geleneksel tıbbın ilk merkezleri ortaya çıktı.

Halk hekimliğiyle Şamanlığı sentez eden Türk neo-şamanlarına örnek olarak Altaylı D. Mamıyev'i, Yakut V. Kondakov'u, Hakasyalı V. Topoyev'i ve T.Kobejikova'yı (Bu sonuncu Kenin-Lopsan'dan şaman eğitimi almıştır.), özellikle baş şaman adlandırılan Tuvalı M. Kenin-Lopsan'ı ve tanınmış Tuvalı kadın şaman Ay-Çurek'i, Buryat B. Rinçinov'u göstermek mümkündür. Bunların çoğu üniversitelerde, araştırma kurumlarında çalışan bilim adamlarıdır. Örneğin Valeriy Topoyev, psikolojik bilimler doktoru, Hakasya Araştırma Enstitüsü'nde (Abakan) etnopsikoloji laboratuvarı başkanıdır, hem de 20 yıldan fazladır ki pratik neo-şamandır. 
Ancak unutmamak lazımdır ki Neo-şamanlık her ne kadar geleneksel tıpla temsil olunsa da buna ek olarak, ulusal kültürlerin canlanmasına ve geleneksel dinlerin şekillenmesine aynı oranda yoğunlaşmıştır. Diğer taraftan Türk neoşamanlarını farklandıran önemli faktörlerden birisi de onların toplumsal etkinliklerde faal iştirakı, resmî tören ve bayramların (örneğin Isıah, Tigir tayi, temizlik ritüelleri vb.) baş aktörü olmasındadır.

Türk Neo-şamanlığının en başlıca ve seçici özelliği onun eski bir gelenek üzerinde yeniden yapılanmasıdır. Buna Şamanlığın inşası demek daha doğru olardı, ancak biz bu fenomeni Türk Neo-şamanlığı olarak öğreniyoruz. Çünkü burada geleneksel Şamanlığın inşası ile yanaşı dünya Şamanlığının tecrübesi, okültizm öğretilerinin teorik ve pratik uygulaması, tıbbi ilimlerin tatbiki, yeni magik bilgilerden yararlanma, ezoterizm vs. kendini gösterir. Türk neo-şamanları da Batı dünyasının neo-şamanları gibi genelde şehirlerde ve belli bir dernek veya merkezde toplanıp, tedavi uygulaması yapmakta, bunu hem geleneksel Şamanlık-tan hem de modern tıptan öğrenerek uygulamaktadırlar. Onların başlıca bilgi kaynağı Batı Şamanlığında olduğu gibi geniş şaman literatürüdür.

Şamanlığın canlandırılması beraberinde yeni bir faaliyet alanı olan halk şifa merkezlerinin genişlemesine neden oldu. Bu halk hekimliği de kendi uygulamalarını şaman geleneğinin üzerinde inşa etti. Özellikle vurgulamak lazımdır ki Sibirya Türk şamanlığı perestroyka ${ }^{3}$ ile birlikte bir canlanma sürecine girdi. Bu eskiden var olanın yeni şartlar ve koşullar dahilinde ihyasıdır. Hristiyanlık ve Lamaizm gerileme yaşadığı bir zamanda buna paralel olarak Şamanlığın yeniden inşa süreci başlamış oldu. Bunu Tuva'da dinî kuruluşların faaliyetleriyle ilgili bir raporda da görmek mümkündür. Özetle, 1981'de Tuva'da 24 şaman vardıysa, 1989'da bu rakam 43'e yükseldi (Хомушку, 1998: 103-106). Aynı durum diğer Sibirya Türk halkları - Teleütler, Çelkanlar, Altaylılar, Şorlar vb. için de geçerlidir (Батъянова, 1999: 309-323; Батъянова, 2005: 150164; Сыченко, 2000: 114-127; Сыченко, 2002: 69-65; Сыченко, 2004: 73101; Харитонова, 2003: 130-140). Hatta Burhanizm'in Şamanlığı sıkıştırıp çıkarttığı Hakasya'da da yeni-yeni "vergi alan şamanlar" ortaya çıktı. Bu ise tipik Türk neo-şaman geleneğinin şekillenmesi anlamına gelir.

3. Rusça bir terim olan perostroyka (перестройка), Türkçeye "yeniden yapılanma, reform" adı altında çevrilebilir. 1980'li yıllardan itibaren gerçekleştirilen ekonomik ve siyasi sistemi yeniden yapılandırma ve reform hareketlerine verilen ad olarak perostroyka 1979'da dönemin devlet başkanı L. Brejnev tarafından önerilmiş, ancak esasen M. Gorbaçev tarafından gerçekleştirilmiştir. SSCB'de sosyalizmin artık işlemez hale gelmesi üzerine ekonomiyi biraz serbestleştirerek devletin bütünlüğünü korumaya çalışan Gorbaçev, tam aksine devletin parçalanmasına sebep olmuştur. Ekonomi ve devlet yönetimine daha liberal bir yaklaşımla devlet mekanizmasını hantallıktan kurtarmağı hedefleyen perostroyka devlet kurumları ve işletmelerine özerklik vermiş, bir çok alanda bakış açısının değişmesine neden olmuştur. 
Türk Neo-şamanlığını Batı Neo-şamanlığından ayıran temel noktalardan biri de "şaman hastalı̆̆ı" adı altında "vergi almak veya göreve çağrılmak"tır. Neo-şamanlar da geleneksel Şamanlıkta olduğu gibi ecdat şaman ruhu tarafından bu göreve çağrılır. Her ne kadar neo-şamanın klasik şaman gibi parçalanması, etinin ruhlar tarafından yenilmesi, iç organlarının temizlenmesi, kulaklarının delinmesi ve gözlerinin yenilenmesi olayı olmasa da (veya yaygın olmasa da) seçilmişlik, kalıtsalık ön plandadır.

O hâlde Türk Neo-şamanlığının en belirgin özelliği onun bu veya diğer formda kendini seçilmişlik kategorisiyle nitelemesidir. "Ruhlarla kalıtsal olarak ve çoğu zaman zayıflatıcı bir hastalık yoluyla iletişim kurma yeteneğini elde eden "ruhlar tarafından seçilmiş kişi", kendisi ve soyundan gelenler için olumsuz sonuçlara yol açmadan, yolundan vazgeçemezdi. Şamanik yol, bir Altay şamanının yaşamına sıradan bir insanın yaşamından çok çok elverişsiz olan bazı kısıtlamalar ve sorumluluklar getirdi. Sıradan bir insan, öğrenmekle şaman olamazdı. Sıradan bir insanın yaşamı ile Şamanik bir "mesleğe" kalıtsal olarak önceden adanmış bir insan arasında neredeyse aşılmaz bir çizgi vardı. Bu nedenle, geleneksel toplumda "profesyonel bir şaman" olma arzusu neredeyse yok gibiydi (Доронин, 2013: 86).

Okumakla, eğitim sürecinden geçmekle, şaman pratiği yapmakla kendini şaman addedenler her ne kadar kendilerini vergi almış bilseler de geleneksel Şamanlığın dışında kalmaktadırlar. Ancak onlar buna makul bir argüman getirirler: Herhangi bir geleneksel şaman da kendisine ritüel uygulama becerilerini ögreten bir akıl hocasına sahip olmadan kamlık yapamaz. Tüm bu varsayımların sonucunda Kançır-oolun başkanlığında Tuva'da şaman okulu "HattıgTayga" adlı manevi eğitim kurumu açıldı. Oraya bir "seçim yarışması" temelinde giren ilk kız öğrenciler ortaya çıktı: Radyoda şamanların okula alınmasıyla ilgili bir duyuru duyduktan sonra, oldukça iyi konumda bulunan insanlar, bürokratik aygıt, eğitim alanında çalışanlar bu okula akıştılar (Харитонова, 2006: 170). Bu da kendi hâlinde şaman geleneğinin hızlı bir biçimde canlanmasına neden oldu. Neo-şamanlık ya geleneksel şaman pratiğinin evrimi ya bir bütün olarak gelenek, doğal canlanma formunda ya da şamanlığın yeniden inşası şeklinde kendini gösterdi. Ancak modernize edilmiş Türk Neo-şamanlığ 1 bu veya diğer şekilde geleneksel Şamanlığın tamamen yozlaşmasına neden olmur, aksine bu süreç doğal bir gelişimin sonucudur ve modern dünyada Şamanlığı yaşatmanın tek yoludur.

Amerika, Afrika, Avrupa, Orta Asya ve Sibirya dahil modernleştirilmiş Şamanlık veya Neo-şamanlığın muasır biçimlerinin neler olduğu, bu yeni fenomenin özellikleri ve en önemlisi de bölgeden bölgeye farklılık göstermesi Şamanizm üzerine yapılan son iki disiplinler arası uluslararası kongrede tartışıldı. Bunlardan biri 7-12 Haziran 1999'da A. V. Anohin'in, N.P. Dırenkova'nın, S. 
M. Şirokogorov'un anısına adanmış "Şamanizm ve diğer geleneksel inançlar ve uygulamalar" adı altında Moskova'da gerçekleşen kongre, diğeri de 9-21 Temmuz 2001'de "Ekoloji ve geleneksel dinî ve büyülü bilgi" adı altında Rusya: Moskova-Abakan-Kızıl - üçgeninde yapılan sempozyum oldu. Bu sempozyumda şaman ve biosfer, Şamanlık ve ekoloji problemler, şaman ve psikoloji vs. gibi konular ele alındı. Bu iki bilimsel platformda dünyanın çeşitli yerlerinden gelmiş bilim adamları (bazıları hem bilim adamı hem de pratisyen şamandı) Neo-şamanlığın bütün taraflarını konu edinen bildirilerle meseleye geniş perspektiften bakmaya çalıştılar.

Sibirya Türk geleneksel Şamanlığı başka halkların Şamanizminden farklandığı gibi Neo-şamanlık kavramı da Türk şamanları için göreceli, farklı bir anlam taşıyor. Şaman geleneğinin kesintiye uğradığı ve zaten tamamen unutulduğu yerlerde klasik Şamanlığın hem iç yapısının hem de mitolojisinin yokluğu, doğadaki Şamanik kontrolün artık mevcut olmaması, herkesi bağımsız olarak şaman yapabilmektedir. V. Haritonova'nın da vurguladığı gibi, soy üyeleri şamanlarının çoğunluğu toplumda yaygın olmasalar da, bilgilerini ve yeteneklerini Sovyet rejiminden saklayan gizli Şamanlık yapanlar da vardı. Şu anda bu varsayımların doğruluğunu kontrol etmek kolay değildir, ancak (neo) şamanlar bile bunu yapmaya çalışmaktadır, örneğin Buryatya'da. Şamanik mesleğin kalıtsal bir mesele olduğu fikri yaygın olduğu için, o zaman tüm neoşamanlar soylarında ata-şaman ruhu bulmaya çaba göstermektedirler. Tüm bunlar şu anki "son"un kim olduğunu merak ediyor: onlar geleneksel şamanların izinden giden, onların yollarını tekrar etmeye çalışan, bilgi ve becerilerini kaybetmemeye çalışan takipçiler mi, yoksa şamanlardan sonra ortaya çıkıp, görevlerini ve işlevlerini miras alanlar mı (Харитонова, 2006: 8).

Sibirya Türk Şamanlığının yeniden canlanması, aslında şaman geleneğinin doğal evriminden ve aynı zamanda yeniden canlanmış unsurlarından başka bir şey değildir. Şamanlık onsuz da Sibirya'nın bütün bölgelerinde vardı. Burada söz konusu olan günlük işlerle uğraşan şamanlard. Klasik anlamda inisiyeden geçmiş şamanlar bazı Türk kavimlerinde, örneğin Hakaslarda ve Şorlarda tarihe karışmıştı. Şaman yeteneklerinin soyla geçtiğini savunan şimdiki Hakas, Şor şamanları bu yeteneklerini çoğu zaman komşu akraba halklardan, örneğin Tuvalılardan, Altaylı kişilerden öğreniyorlar.

Neo-şaman olarak kabul edilenler Şamanik uygulamaya, geleneksel Şamanlığı öğrenmekle yöneldiler. Bunların bazılarının atalarından kalma şaman ruhları ve çocukluktan keşfedilen yeteneklerinin olduğu görüldü. Bunlardan birçoğu psikoteröpik, bazıları modern psikoteknik yöntemleri öğrenmek için çeşitli kurslarda eğitim aldılar. Şimdi Sayan-Altay Türkleri şamanlarının bazıları Tuva'da Şamanik tekniklerin geliştirilmesi yönünde eğitim alırlar. 
Tuva'da şaman yetenekleri olanlara ve eğitim kursunu geçenlere Kenin-Lopsan sertifika vermekle, onları belgeli şamanlar yapmaktadır.

Buna ek olarak, Sibirya Türklerinde "Neo-şamanizm" terimi ve neo-şaman adı altında çalışan insanları başka bir sınıfa ait etmek mümkündür. Yukarıda da denildiği gibi Neo-şamanizmin öncelikle Sibirya Türkleri ve Kuzeydoğu halkları arasında az da olsa canlılığını koruyan geleneksel Şamanizm varyantları temelinde yeniden şekillenmeye başladığı bir gerçektir. Bu anlamda, Sibirya Şamanlığını entelektüel insanların suni şekilde geliştirdiği Şamanlıktan ayırmak lazımdır (Харитонова, https://postnauka.ru/video/48994). Neo-şaman, bugün geçmişte ve hatta $\mathrm{XX}$. yüzyılın başında az da olsa mevcut olan geleneksel şamandan çok uzaktır. Neo-şamanlar genç, yüksek eğitimli, seküler bir işe sahip ve kariyer yapmış modern insanlardır. Ancak bu onların şaman olmalarına engel değildir, çünkü onlar "ruhlar tarafından seçilen" birkaç nesil şaman geleneğine sahip, soyunda şamanlar olanlardır. Örneğin bugün bir çok ülkede tedavi seansları gerçekleştiren Altaylı kadın şaman Alla Gromova soyunda birkaç şaman olduğunu iddia eder.

Sibirya Türk ve gayri-Türk halkalarının Neo-şamanik hareketinin kesintisiz izlerini bulmak için diğer kültürlere karşı bir direniş ve kendini koruma mekanizmi olduğunu da söylemek gerekir. Çünkü yakın denilebilecek bir tarihte Rusya'dan ithal edilen kültürlerin, dinlerin baskısıyla bu halklar kişisel ruhani yollarını kaybetmek tehlikesiyle yüz yüze kalmışlardı. Ayrıca, XX. yüzyılın sonları ve XXI. yüzyılda bir uyanış yaşayan Sibirya Türkleri, aynı zamanda diğer küçük halklar da hızlı bir şekilde kendi geleneklerine yöneldiler. Hatta eski dinî inançlarını yeniden inşa etmek yolunu tuttular. Şamanlığın gelişmesinin altında yatan etmenlerden biri ve birincisi de bu olsa gerek.

XXI. yüzyılda artık örgütlenmiş şamanlar, toplantılar düzenliyor, kendileri de bilimsel toplantılara katılmakla bildiri sunar, kamlık yapar, tedavi seansları geçirirler. Sibirya şamanları Tuva'nın başkenti Kızıl'da 10 Haziran 2018'de düzenlenen uluslararası katılımlı Birinci Tüm Rusya Şamanlar Kurultayı'nda Sibirya, Moğolistan, Avrupa ve diğer ülkelerden gelmiş şamanlar (aslında neoşamanlar) bir araya geldiler. Bu kurultayda Sibirya Şamanlığı ile beraber Filipin, Kore, Japon, Avusturya, Amazon, Meksika, Orta Asya, hatta Gürcüstan vb. ülkelerde şaman geleneği, Neo-şamanlığın problemleri, magiya, din, halk hekimliği, parapsikoloji, neröfizoloji, değişen bilinç durumu vs. ele alındı. Bir dizi problematik konularla beraber bu kurultayda Rusya'nın en büyük şamanını da seçtiler. Oylama gizli yapıldı, ancak sayım halka açıktı. Tuvalı şaman Kara-Ool Dopçun-Ool büyük bir farkla kazandı. Rusya'nın Yüce Şamanı böyle seçildi.

Uluslararası katılımlı İkinci Tüm Rusya Şamanlar Kurultayı, 14-16 Haziran 2019 tarihleri arasında yine Tuva'nın başkenti Kızıl kentinde düzenlendi. Dün- 
yanın çeşitli yerlerinden gelmiş bilim adamları ile yanaşı bu kongrede Tuva' nın merkezi dinî şaman örgütü, yerel dinî Şamanik - "Adıg-Eeren", "BoruEeren", "Tos Geyiği”, "Monge Geyiği"; Buryatya Cumhuriyeti şaman örgütleri: "Boo Darkhan", "Deezhi”, "Şarvay"; Rusya'nın en büyük şamanı - Dopçun-ool Kara-ool Tülüşeviç ve Rusya'nın her yerinden St. Petersburg, Perm, Yekaterinburg, Novosibirsk, Krasnoyarsk, İrkutsk, Ulan-Ude'den şamanlar katıldı. Beyaz Rusya ve Moğolistan'dan şamanlar da hazır bulundu.

Sovyetlerin çökmesinden sonra ateist baskıdan kurtulan Sibirya Türkleri eski şaman inancına dönmekle beraber yeni dinî konfesiyalar da kurdular. Hristiyan olanlar, Rus nüfusla beraber Hristiyanlığ yeniden güçlendirmek için derneklerde, kilise örgütlerinde toplandılar. Buna örnek olarak Ortodoksluk, Eski İnananlar, Protestan ve neo-dinî hareketleri göstermek mümkündür. Lamaist olanlar da Buda tapınaklarından dışarıda yeni dinî konfesiyalarda birleştiler. Öğreğin Krişnacılık, Yoga öğretileri vs. Ancak Şamanlık yeni bir çağa ayak basmasına rağmen hâlen de dinî konfesiyalar karşısında çok zayıf kalmaktadır. Nitekim Hristiyanlık ve Lamaizm bir din olarak algılanırken, tiyatral gizemleri ile Neo-şamanlık, tam olarak ruhsal kültürün bir parçası olarak canlanma gösterir. Hatta bazı bölgelerde, örneğin Hakasya'da Şamanlığın canlanması çok zayıf hızla gitmektedir. Bu ise büyük ölçüde bu bölgede Stalin Kızıl teröründen sonra geleneksel şamanlardan sağ kalanının olmamasıyla ilgilidir.

Özetle Sibirya Türk Neo-şamanlığı yakın tarihe kadar var olan güçlü şaman gelenğinin yeniden canlandırılmasıyla yeni teknik ve etkileşimleri bünyesine almakla karakterize edilir. O nedenle de ister geleneksel şamanın isterse de neo-şamanın edebi imajı yazılı edebiyatta, sinemada, tiyatroda ve hatta resim eserlerinde, fotoğraflarda sık sık görülmeye başladı. Nitekim modern kültürde Batı rasyonalitesinin bir antipodu ve alternatif bir maneviyat örneği olarak var olan bir şaman imgesi, sanatsal kültürde aktif olarak kullanılmaktadır. Sibirya halklarının ulusal edebiyatı şamanların görüntüleri, ritüel sahneleri, faaliyetleriyle ilgili olay örgüleriyle doludur (Непомнящих, 2016: 76-80; Непомнящих, 2019: 180-186). Sibirya şamanının imajı edebiyattan resime, sinemadan sahneye kadar taşındi.

Sovyet literatüründe şamanlar genellikle olumsuz karakterler, düşmanlar, kötülükler, çeşitli hileler yapan ve bu hilelerin yardımıyla kendi soydaşlarını korkutan, bir kural olarak açgözlü, fakirlerin son mülkünü ele geçirmeye çalışan tehditkâr varlıklar olarak tasvir edildi. Bunları, 1960'ların, 1970'lerin edebiyatı da takip etti. Örneğin A. Passard'ın, J. Troşev'in eserleri. Bu gelenek hatta 1980-1990'ların edebî eserlerinde de devam etti. Hatıra edebi türünde, yazarların gençlik yıllarında şaman kamlığında iştirakları, şamanların olağanüstü tavırları ele alındı. Bunlardan Aliteta Nemtuşkina'nın "Göksel geyik düşlerim" (1987), Galina Kaptuke'nin "Küçük Amerika" (1991) ve Yeremeya 
Aypina' nın "Sönmekte olan ocakta" (1998) adlı eserlerini örnek olarak göstermek olur (Непомнящих, 2019: 181-182).

Eski Sovyetler döneminden farklı olarak şamanlar, hem edebiyatta hem sinemada hem sahne sanatlarında hem de resim sanatında olumsuzluk sendromundan kurtulmuş oldular. Az da olsa (neo)şamanın bazen olumsuz taraflarını konu alan eserlere rastlamak mümkünse de bu genel perspektifte o kadar da önemli değildir. Ayrıca şamanın davulu, kostümü, diğer gereçleri, şaman mitolojisi hem yerli hem de yabancı sanatçıların resimlerinde sunulmaktadır. $\mathrm{Bu}$ ressamlardan Vladimir Nikişini, Timofey Stepanovu, Azat Minnekayev'i, Luis Tamani'yi, Pablo Amaringo'yu, Susan Seddon Boulet'i, Norval Morisso'yu ve diğerlerini göstermek mümkündür.

Diğer taraftan şaman davulunun ses-ritmik bileşeni, şaman müziği diğer müzikal geleneklerle birleşerek yeniden sahnelendi ve modern müzik kültürünün bir parçası hâline geldi. Buraya bazı şamanların müzisyenlik yetkisini, şarkıcılığını, sanatçılığını da ilave etmek mümkündür. Ayrıca şaman motifleri sadece, icracı olan şamanların değil, hem de diğer müzisyenlerin müzikal yaratıcılığında yer almağa başladı. Tek kelimeyle XXI. yüzyılda Neo-şamanlık konsepti iletişimsel ve aksiolojik ${ }^{4}$ yönleriyle öne çıkmış oldu.

\section{Sibirya Türk Neo-Şamanları veya Şamanlığın Modifikasyonu}

Sibirya Türk geleneksel inanç sistemini geliştirmekle Neo-şamanlığa yeni bir anlam katan XX. yüzyılın şamanları genelde daha ziyade şehir merkezlerinde, şaman dernek ve topluluklarında, şaman vakıflarında örgütlendiler. Bugün Tuva Şamanlığını yaşatan ve koruyan Monguş Kenin-Lopsan buna canlı örnektir. Kenin-Lopsan'ın faaliyetlerinin çok yönlülüğü, bir de onun gerçek şaman uygulamaları yapması Z.Samdan'ın da yazdığı gibi Tuva'nın kendisinde ve sınırlarının çok ötesinde bilinmektedir. O, birkaç on yıldır ihtiyacı olan herkese yardım ediyor. Köylerden, küçük yaşayış yerlerinden ve Tuva Cumhuriyeti'nin şehirlerinden sonsuz bir ziyaretçi akışı - Şamanistler ve Budistler, öğretmenler ve araştırmacılar, yazarlar ve sanatçılar, ziyaretçiler ve gezginler - hepsi yardım, tavsiye ve kendini kurtarmak için ona geliyorlar (Самдан, 2019: 168).

Aynı şekilde Yakutya'da da geleneksel Şamanlığın bazasında yeni bir Şamanlık (Neo-şamanlık) kurulmuştur. Nitekim kendini ak şaman (ayıl oyun) adlandıran ve insanları tedavi eden Vladimir Alekseyeviç Kondakov aynı

4. Felsefi bir terim olan aksioloji Yunanca olup değerler teorisini (insani değerleri) öğrenir ve etik (ahlaki değerler) ve estetik (güzellik anlayışı) olmak üzere ikiye ayrılır. Aksiyoloji, doğal değerler, bunların gerçeklikteki yeri ve dünyanın değer yapısı, yani farklı değerlerin kendi aralarındaki sosyal ve kültürel faktörlerle ve kişilik yapısı ile ilişkisini inceler. Aksioloji Sokrates'ten yüzü beri felesefenin önemli bir bölümüdür. 
zamanda bir şaman araştırmacıdır. O kendisini en yüksek şaman kategorisine ait ediyor. Kondakov, "Ürüng Aar Toyon" adlı Geleneksel Tıp Derneği'ni ve geleneksel tıp sorunları ve inançları üzerine araştırma kuruluşunu kurdu ve ölümüne kadar (2019) bu organizasyonun başkanı olarak kaldı. Yakutya'nın modern şamanları, udaganları (kadın şamanları) ve şifacıları onun etrafında birleşmiş oldular. Tıp ve psikoloji alanlarında doktor unvanı almış profesör Kondakov tıpkı M.Kenin-Lopsan gibi bilim adamı, yazar ve pratisyen-şamandır. Eserlerinin ana teması şifa ve Şamanizm üzerinedir (Hata! Köprü başvurusu geçerli değil.).

Türk Şamanlığı için özgü olan bir durum da şaman ananesinin taşıyıcılarının araştırmacı olmasıdır. Bu kendi kültürünü araştıran ve kendisi de bir şaman olan araştırmacıları hermenötik ${ }^{5}$ cazibeden kaçmaya imkân veren esas olgudur. Bu tip araştırmacıların çalışmaları, dikkati kendi kültürünün ezoterik alanlarının incelenmesine çevrmediği sürece etkili kalacaktır. Her şaman kendi kültürünü bir araştırmacıdan ve neo-şamandan daha net bilmektedir ve onların bilgisi güvenilir sayılabilir. Şamanlığın ezoterik bilgisini az çok bilenler yalnızca şamanlarla yakın iletişim kurma şansı olan ve kendisi de bu bilgini şamanlardan alanlardır. Kendileri şaman olmayan ve kültürün taşıyıcısı olmayan insanlar bir dış gözlemciden başka birisi değildir. Kısacası, Kızılderili Şamanlığını, Afrika Şamanlığını ve nihayet Türk Şamanlığını öğrenmekle onun iç yapısına vakıf olmak mümkün değildir. Oysa bu konuda bir Teleüt, Altaylı, Hakas, Tuva, Yakut, Şor araştırmacı neo-şamanı daha şanslıdır. Burada söz konusu olan rastgele herhangi bir neo-şaman değil, kültürün içinden çıkmış, soyunda ve aile geleneğinde şaman olan araştırmacı pratisyen şamandır. Ancak Türk Şamanlığı Sovyet döneminde ağır baskılara maruz kaldığından nüfus sayı az olan Türk toplumlarında Şamanlık geleneği oldukça zayıflamıştır.

Rusya'nın Kemerova vilayetinde yaşayan ve bugün sayıları 17-20 bin cıvarında olan Şorlar (ayrıca Altay'da, Hakasya'da ve diğer bölgelerde de Şorlara rast gelmek mümkündür) eskilerde güçlü şaman geleneğine sahip olsalar da Sovyet rejimi zamanında bu gelenek hemen hemen yok olup gitmiştir. Otantik şaman geleneğinin modifikasyona uğrayan varyantı, 2000'lerde başlayarak Dağlık Şorya'da kayda alınmıştır. L. N. Arbaçakov tarafından yürütülen saha araştırması, davulu olmayan birkaç sözde şaman tanımladı, ancak

5. Hermenötik Yunanca olup yorumcu (yorum sanat1) anlamına gelir ve ilkin Hristiyan teolojisi alanındaki yorum tartışmalarından ortaya çıkan bir disiplindir. Ancak sonralar bu terim genel anlamda yorum araştırmalarıyla ilgili felsefi bir disiplin hâline gelmiştir. Felsefi disiplin olarak XX. yüzyılda edebî metinlerin yorumu sonucunda ortaya çıkmıştır. Hermenötik akım Yunan Tanrısı Hermes'le bağlansa da aslında onunla hiçbir ilgisi yoktur. Esas kurucusu Alman filozofu Wilhelm Dilthey (1833-1911) olarak bilinir. 
şaman vergisi alma geleneğinin hâlen de korunduğu tespit edildi. Şorların modern şaman geleneğinde, birkaç tür ritüel işlev vardır: Şifa ritüelleri (özel bir ismi yoktur), alas temizleme ritüeli, kabaran ruhunu yakalamak, merhumun ruhunu öteki âleme yola salmak, kovayla kamlık yapmak ve terk edilmiş eski yurt yerine gezi düzenlemek ( https://www. culture.ru/objects/452/obryad-ochisheniya-shorskoi-shamanki-a-o-kuspekovoi). Bugün az da olsa Şamanlık kültürünün korunduğu yer Novokuznetsk kentinde yerleșen Şor kültür merkezi olan "Aba-Tura" ve Novokuznetsk bölgesinin Sosnova köyünde kurulan "Altın Çer" adlı halk topluluğudur. Şorların tanınmış davulsuz şamanı 1930 doğumlu Akulina Kuspekova'dır. Davulsuz kamlık yapsa da Kuspekova şaman sanatına diğer Şor şamanları gibi, şaman hastalığından sonra başlamıştır. Kendisinin anlattığına göre ruhlar ona "Ya öleceksin ya da şaman olacaksın", diyerek hastalık gönderdiklerinde, o Şamanlık yapmak zorunda kalmıştır (Арбачаков Александр Никитич (2004: 26-28). Modern Şor şamanlarından biri de İgor İdimeşev (Kam İ̀gaş) dir.

Değiştirilmiş şaman versiyonunda şamanların pratik uygulamaları bir çok hâlde davul olmadan kayın ağacından yapılmış süpürgeleri, yabani gül veya alıç, arçın dalları, eşarplar, bıçaklar, tavalar ve hatta ikonalarla (Hristiyan azizlerinin tasviri) hayata geçirilmeye başladı. Bazı şamanlar kamlık ritüelinde topşur (telli müzik aleti); komus; orbo çırpıcı; kamçı; yayik bantları; meşale; kömürler; eski bronz bıçaklar ve taş aletler; şekillerinde vücut parçalarına benzeyen taşlar; hayvan organlarında bulunan taş oluşumları; geyik veya çiftlik hayvanların diz kapağının kemikleri; kuzu omuzu vs. gibi aletlerden de yararlanırlar. Bunlar kendilerini şaman adlandırdıkları gibi toplum da onlara çoğu kez şaman der, tedavi ve başka işler için onlara baş vurur. Genel kanaate göre davulsuz şamanlar orta ve zayıf şamanlardır. Ancak davulsuz şamanların büyük bir kısmı zamanla kendilerine davul yaparak hakiki şaman statüsüne geçmiş olurlar.

Sibirya Türk şamanlarının, özellikle Sayan-Altay şamanlarının modernlik adına davulsuz kamlık yapmaları onlara ruhların davul yapma izni vermedikleri, bu yararlanılan eşyaların davuldan önce var olduğu, davulun Sovyet döneminde yasaklanması vb. sebeplerle izah edilir. S. P. Tühteneva bu durumu şöyle izah edir: “... Altay Şamanizmi (geniş anlamda L. P. Potapov tarafından kullanıldığı şekliyle ve dar anlamda Altaylıların geleneksel dinî ve ideolojik sistemi olarak) modernize edildi ve dönüşümünün sonucunda şöyle bir manzara ortaya çıktı - şamanlar var, ancak Şamanizm yoktur (Тюхтенева, 2004: 267).

Davulsuz kamlık yapan şamanlar Sibirya, özellikle de Türk şamanlarını Batı dünyasının neo-şamanlarından ayıran başlıca etmenlerden biridir. Modifikasyona uğrayan Hristiyan Sibirya Türk şamanlarından bazıları ikonayla 
kamlık yapar, teşhis koyarlar. Nitekim bazı vaftiz edilmiş şamanların uygulamasında Ortodoks dualarıyla karşılaşılır. Bu sadece tüm dinleri eşit kabul eden modern inisiyeler arasında değil, aynı zamanda eski neslin şamanları arasında da bulunabilir. V. Haritonova Hakasya'da, yaşlı bir bayan olan Tadi'nin davulsuz, ancak Hristiyanların Tanrının anası adlandırdıkları Meryem'le bebek İsa'nın tasviri olan ikonayla "Babamız" duasını okuduğunu, sonra tedavi seansına başladığını yazır (Харитонова, 2003: 130-140).

Sibirya Türk Şamanlığını Batı Neo-şamanlığından ayıran bir nokta da Hristiyanlaşmış toplumun neo-şamanlarının kamlık zamanı kilise duaları okumaları, Meryem'i, İsa'yı yardıma çağırmalarıdır. Bu örnek tek olmayıp Altaylı şamanların bir çoğunun Hristiyan Ortodoks dualarını bildikleri ve bundan Şamanlık zamanı yararlandıkları teziyle de desteklenir. Örneğin kadın şaman Sargon'un sabah ve gece vakti Ortodoks mezhebi duaları okuduğu bilinir. Aynı zamanda Budist bölgelerinde her ne kadar kural olarak, şamanların ve lamaların işlevlerinin ayrılmasına dair bir fikir varsa da, her iki dinsel geleneği uygulayan özel bir şaman/lama kategorisinin varlığı da bilinmektedir.

Müslüman yerleşim bölgelerinde de inançların ve dinî ibadetlerin Şamanlıkla bir karışımının olduğu görülür. Mesela, Omsk bölgesinin Korjas köyünde 1977 'de İshak mollanın atalara ait mezarlıkta kurban törenini nasıl gerçekleştirdiği buna örnek olabilir (Харитонова, 2006: 132). Bu değiştirilmiş şaman tedavi seansını uygulayıcıları genelde davulsuz ve özel kostümsüz olur.

Müslümanlar arasında benzer bir şaman törenine ben, 1989 yılında Özbekistan'da kadın bakşıların Müslüman duaları okuduktan ve İslam büyüklerinden yardım diledikten sonra kamlığa başladıklarına şahit oldum. Hatta Orta Asya şamanları, Müslüman geleneklerini de şaman gösterileri içine katarak çiltan olarak adlandırdıkları kırkların ruhuna kamlık yaparlar. Hem de kamlık zamanı ne davuldan ne de özel giysisinden yararlanırlar (Bayat, 2006: 239). Şamanlıkla İslam, Orta Asya'da iç içe yaşadığından şamanlar, birtakım zorlu anlarda Müslüman evliyalarını yardıma çağırır, merasime başlamadan önce "Bismillah" der, bazen Şamanlık vergisini İslam mukaddeslerinin kabirleri üzerinde yatmakla alırlar. Orta Asya etnografik malzemelerinin en iyi derleyicilerinden ve bilicilerinden biri olan A. Divayev de bu durumu gözlemlemiştir. Onun yazdıklarına göre Kazaklar, hastalarını tedavi etmek için, hem şamanları, hem de Cehriye kolunun kalenderlerini davet ederler. Şamanlar da bazen hastaları mollanın yanına gönderirdiler (Диваев, 1902: 80). Tek kelimeyle Sibirya Türklerinde Hristiyanlık'la, Lamaizm'le Şamanlık yan yana yaşıyorsa ve etkileşim hâlindeyse, Orta Asya'da İslam'la Şamanlık iç içeydi. Bu durumda Türk Neo-şamanlığının başlangıçtan farklı bir gelişim sergilemekte olduğu ve za- 
manla modifikasyona uğradığı açıktır. Ancak bazı Müslüman bakşılar (şamanlar) sopayla, değnekle, tokmakla da kamlık yapır, bu gereçleri tedavi aracı olarak kullanırlar.

İslamlaşma Orta Asya ve Kazakistan Şamanizmini özel bir fenomen hâline getirdi. O nedenle de Orta Asya Şamanlığı Sibirya Şamanizmiyle karşılaştırıldığında bir çok farklı noktaların olduğu görülür. V. Basilov, derlediği materyalin analizinde hem Orta Asya'da hem de Kazakistan'da ve Sibirya'da ortak şaman geleneğinin izlerinin olduğu kanaatine varır (Басилов, 1992: 201). Buna rağmen Orta Asya bakşılarının (falbin, perihan) davul veya her hangi müzik aletinden yararlanmadığını söyleyebiliriz.

V. Basilov karşılaştırmalı tipolojik karaktere sahip çalışmalarında İslamiyet'in Şamanlığı transformasyona uğrattığını, ancak bu sonuncunun da halk sufizminin oluşmasına katkı sağladığını belirtir. Doğal olarak Şamanlığın geleneksel kültün esas figürü olduğu Türk halklarıyla dinî-sosyal hayatta esas yönlendirici ideolojinin İslam olduğu bir topluluğun Şamanlığ 1 arasındaki farkların büyük olacağı kaçınılmazdır. E. Revunenkova İslam'la Şamanlığın münasebeti ve Müslüman ülkelerinde Şamanlığın farklı durumu hakkında yazarken Basilov'un fikirlerinin ne kadar önemli olduğunu şöyle değerlendiriyor: "Yazar, Orta Asya ve Kazakistan Şamanizminin nasıl önemli bir İslamlaşma geçirdiğini ve İslam'ın mitolojisini ve ritüel özgüllüğünü nasıl benimsediğini gösteriyor. Buna karşılık, Müslümanlık öncesi gelenekleri asimile eden İslam, ısrarla onları doktrinin ruhuna uygun bir biçime dönüştürdü. Ancak aynı zamanda şaman gelenekleri hayatta kaldı ve Müslüman dininin çeşitli alanlarına nüfuz etti. Sufi ritüelleri, özellikle şaman gelenekleri açısından zengindi. Sufi ayinine katılanların kendilerini bir coşku hâline getiren sufi şevki (veya trans hâli) - zikir tasvirleri çok etkileyicidir." (Ревуненк-ова, 2012: 34). Hem Basilov hem de Revunenkova doğru olarak şamanlığın transformasyon geçirdiğini vurgulamaktadırlar.

A. Yarlıkapov bir makalesinde geçen yüzyılın sonundan, tıbbi uygulamaların ağırlıklı olarak mollaların elinde yoğunlaştığını yazar. Onun kanaatine göre otacılar, şifacılar küçük ruhsal bozuklukların, yaralanmaların ve morlukların tedavisi zamanı devreye girerler. Ruhlar üzerindeki güç, mollalara ve özellikle de "yinli molla" kategorisine girmelerine izin veren özel bir kitabı olan mollara verildi. İlginç bir efsane, bu kitabın kökenini açıklıyor. Allah'ın dilemesiyle, Süleyman Peygamber sadece insanlar üzerinde değil, aynı zamanda daha önce göksel melekler tarafından mağlup edilen ve yerleşik dünyanın dış kesimlerine sürülen vahşi hayvanlar, kuşlar ve yin ruhları üzerinde de güç kazandı. Yenilgiden sonra bile ruhlar gururlarından kurtulamadılar ve esas olarak da çeşitli hastalıklar göndermekle insanlığa zarar vermeye devam ettiler. Eğer bir kişi 
hastalanırsa, Süleymen tüm yinleri bir yere toplayarak tehditkâr bir şekilde onlardan hangisinin hastalığa neden olduğunu sorardı. Hastalığa neden olan yin, hastanın nasıl iyileştirilebileceğini bu korkunç kral peygamber önünde cevaplamak zorunda kalırdı, aksi takdirde Süleyman, ruhu ateşte yakmakla tehdit ederdi. Süleyman, ruhların tüm cevaplarını tek bir kitapta topladı ki özel yetenek sahipleri kitaba bakarak, Tanrı'nın izniyle, insanları iyileştirebilsinler (Ярлыкапов, 2012: 333).

Nogayların inancına göre yin, küçük boyutlu antropomorfik bir yaratık olarak bilinir. Bir insandan ancak dikkatli bir inceleme ile ayırt edilebilir: Yinin el ve ayak parmaklarında eklem olmadığı gibi burunlarının da iç zarı yoktur, yani bir burun deliği vardır (Ярлыкапов, 2012: 333). Yinler adı ile bilinen varlıklar İslam'ın cin olarak adlandırdığı varlıklardır. Yinli molla, Cinci hoca veya üfürükçü ile aynı anlama gelmektedir.

Olga Gorşunova 80'lerin sonunda - 90'ların başlarında Özbekistan, Kırg1zistan, Tacikistan'da, kısmen de Kazakların yaşadığı bölgelerde şaman ve tabiplerle ilgili saha çalışmalarında bir dizi etnografik materyaller derleyerek bu iki geleneksel kurum hakkında bazı tespitlerde bulunmuştur. Ona göre şamanların (bakşi) ve tabiplerin faaliyetleri, yalnızca gerçekleştirdikleri işlevler açısından değil, uygulamada kullandıkları yöntemler bakımından da benzerdir. Hem bakşılar hem de tabipler aynı muskaları (tümarlar), büyüleri (kulauzlar) vb. kullanırlar. Belirli durumlarda, bir şamanı şifacıdan ayırmak zor olabilir, çünkü onlar kendilerini belirli bir kategori ile tanımlamazlar. Buna bakmayarak bunların arasında farklar da vardır. Gorşunova'ya göre, şamanların aksine, şifacılar "seçilmiş kişiler" değiller, ruhlarla ilişkileri ve etkileşimleri daimi hem de dramatik bir bağlantı ile gerçekleşmez. Oysa şaman ve onu "seçen" ruhlar arasında aralıksız bir ilişki mevcuttur. Şifacılar, tıpkı şamanlar gibi, bazen, amacı profesyonel statünü pekiştirmek olan bir geçiş ayininden geçerler. Şaman için, inisiyasyon ayini aynı zamanda ruhlarla bir uzlaşma eylemidir ve bu esnada şaman ile bir ruh veya bir grup ruh arasında bir tür anlaşma yapılır. Ancak adı geçen araştırmacı-etnografın bunu veya bu varsayımı belirli bir kategoride sınıflandırmasına imkân veren temel fark, failin "bilgi" alırken hangi durumda olduğu ve ne tür bir "bilgiye" sahip olduğudur. Mesela bir uzmandan belirli tekniklerin bilinçli olarak özümsenmesi veya kendisi deneysel olarak edindiği becerilerin bir sonucu olarak elde edilen yöntemlere güvenirse, bu durumda söz konusu bir tabiptir. Bunun aksine, şaman, trans hâlinde, rüyada, yani değişmiş bir bilinç durumunda, bilgisinin ana kısmını değilse de önemli bir kısmını almış olur (Горшунова, 2001: 26).

Orta Asya şamanlarının, özellikle kadın şamanlarının rüyada veya her hangi bir sarsıntı hâlinden (kocası tarafından dövülme vs.) sonra vergi alması dikkati çekiyor. Bu ruhlar arasında Sarı kız (bir tür albastı), kara albastı, çiltanlar, diğer 
demonik ruhlar görülmektedir. Tuva ve Hakas şamanlarına göre de albastı, şamanı seçen baş ruhlardan biridir. Hatta Hakas şaman inancına göre en güçlü şamandan da yukarıda albastı ruhu vardır. V. Basilov da Orta Asya'da şamanın kendi karyerasını albastıyla hayali görüşten sonra gerçekleştirdiğini bildirir. Halk arasında bu durum şamanın (bakşının) albastı üzerindeki gücüyle açıklanır. Şöyle ki, bakşı bir zamanlar albastıyı gördükten sonra, sözde onu yenmeyi başarmış ve saçını kendisi için almıştır (Басилов, Кармышева, 1997: 55). Albastının yakasına iğne geçirmekle kendine tabii etmek gibi bir inanç Azerbaycan Türkleri ve Doğu Anadolu Türkleri arasında da çok yaygındır ve bununla bağlı çok sayıda memorat vardır. Orta Asya Müslüman Şamanlığına dönmüş olursak bu bakşı adlı şaman kurumu bir çok taraflarıyla Sibirya Şamanlığından ayrıcalık oluşturur. Bu ise kendine özgü bir Neo-şamanlık formudur ki, eski bakşı, falbin, perihan geleneğinin yeni dinî sistem ortamında varlığını sürdürmesidir.

XX. yüzyılın sonları ve XXI. yüzyılın başlarında Altay'da canlanmağa başlayan Şamanlık veya şaman adı altında faaliyet gösteren farklı tabakalardan insanları görmek mümkündür. Bunlardan bazıları daha teosofik ve ezoterik termi-noloji, "temas kuramları" kavram ve yöntemlerini kullanırsa, bir diğeri Budist tekniklere yönelir, bazıları psişik veya "sertifikalı bir halk şifacısı" olarak çalışır. Çoğunluğu ise geleneksel Altay şaman kavramlarına ve tekniklerine dayanarak tedavi ve temizlik işleri, kehanet ve dualar yapmaktadırlar. Ancak kendini şaman addedenler mutlaka soyunda şaman olduğunu söyleyerek bunu "kanıtlamak" zorundadırlar.

Hatta Şamanlık geleneği olmayan Rusya'nın merkezi şehirlerinde Moskova'da, St. Petersburg'da, Sibirya'nın büyük şehirlerinde (Novosibirsk, Barnaul, Kızıl, Novokuznetsk vb.) olduğu gibi şaman örgütlerine, şifa merkezlerine rast gelmek mümkündür. Bunların bir kısmı Sibirya kökenli insanlarsa, diğerleri de şehirde yaşayan, Şamanlık ve geleneksel tıp konusunda deneyimli olan Rus kökenli insanlardır. Bundan başka Rus kökenli bazı psikotör-apeftler de Sayan-Altay şamanlarının kurumlarına üye olur, hem Rusya'nın merkezi şehirlerinde (Moskva, Petersburg), hem de Sibirya'da çalışırlar. Örneğin, Tuva'nın başkenti Kızıl'da ("Tos Deer" ve "Düngür" adlı şaman derneklerinde) sık sık Moskvalı V. A. Gubanov, ki ataları arasında Slav sihirbazları bulunur, transpersonal pratikleri ve şaman tekniklerini uyguluyor. Onun ve diğer bazı meraklıların sayesinde, bir tür "şaman turizmi" gelişiyor: Moskova'dan şaman uygulamalarıyla ilgilenen bir grup insan genellikle Kızıl'a geliyor ve şamanlardan birini yanlarına alarak tayga-ya - ritüellerin geçirildiği "güç yerlerine" gidiyorlar. Aynı ile Moskvalı N. M. Dobındo Tuvalı şaman Ay-Çurek'ten şaman eğitimi alarak bir kaç yıldır ki Tuva'da çalışıyor (Харитонова, 2006: 312). 
Türk kökenli olmayan üniversite diplomasına sahip başka bir psikolog Vera Sajina, hastalıkları bilimle değil, büyü kullanarak iyileştirmekle ilgilendiği için önce Amerika'ya gitti ve burada yerel şamanlarla çalıştı. Şamanizm geleneklerinin iyi korunduğu Tuva Cumhuriyeti'nde, Sajina becerilerini daha da geliştirdi ve ölülerin ruhlarıyla iletişim kurma yeteneği kazandı. "Yerli Amerikalılar ve Tuva bozkırları bana gökyüzüne nasıl dua edileceğini öğretti. Moskva yakınlarındaki çam ormanları bana kurt radyosunun dalgasını nasıl ayarlayacağımı öğretti. Kırım Denizi bana derin bir meditasyon hâlinde şarkı söylemeyi öğretti” diyor Sajina. Sajina yılın yaz yarısı Tuva'da, kış yarısı için Moskva'daki evinde müssteri kabul ediyor. Bu neo-şaman kadın hatta 2001'de Şaganar'da bir ev satın alarak orada "Uş Möörük" adlı merkez kurmuş ve orasını pratisyen şamanların ihtiyarına vermiştir (https://inosmi.ru/social/ 20160805/237451383.html).

Sibirya Türk Şamanlığı Batı'ya açılmakla, orada konferanslar vermekle Neo-şamanlığa yeni ivme kazandırdılar. Tuvalı Monguç Kenin-Lopsan'ın, Amerika da dahil olmakla bir çok Batı ülkesinde verdiği konferansalar ve şaman uygulamaları buna örnek olabilir. V.Haritonova bu konuda şöyle bir tespitte bulunur: "Yabancıların kendileri, yabancı gazeteciler ve yabancı araştırmacılar buna katkıda bulundular, neo-şamanlarımızı bilimsel konferanslara aktif olarak aldılar. Bu şamanlar çeşitli ülkelere yerleşti - örneğin, İtalya'da kendi kutsal yerini yaratan Tuvalı Ay-Çurek adlı harika bir şaman var ve bu kutsal yer hâlâ Aosta Vadisi'nde korunuyor. 2014 yılında orada bir antropoloji okulu yapıldı ve antropoloji okulumuz yurtdışındaki neo-şamanlarımızı hatırlayarak bu kutsal yeri ziyaret etti (https://postnauka.ru/video/48994).

Aynı ile Yakut Vladimir Kondakov da verdiği konferanslarla, yazdığı kitaplarla Batı şaman dünyasını etkilemektedir. Bu ise Sibirya şamanlığının neden bu kadar popüler olduğu fikrini akla getirir. Bu konuda Altaylı kadın neoşaman Alla Gromova'nın tespitleri ilginçtir: "Sibirya Şamanizmi neden bir mucizeye benzer, bu kadar güçlü bir etkiye sahiptir ki, bir insanın problemlerinin bir anda çözülmesini sağlar? Çünkü bu, dünyanın ilk Şamanizmidir. Şamanizm insan tarafından icat edilmedi, Sibirya'nın ruhu tarafından verildi. Bu çok güçlü bir ruhtur. Binlerce yıl önce bilgisini ilk insanlara aktardı ve onları şaman yaptı. Yavaş yavaş insanlar farklı yönlere dağıldı, farklı halklar, etnik gruplar, ırklar oluştu. Şamanlarıyla birlikte kabileler yeni topraklara taşındığında, Sibirya'nın ruhu ile bağlarını kaybettiler ve Şamanik bilgiyi soyla, babadan oğula aktarmaya başladılar. Örneğin, bazı kabileler Baykal Gölü’ne gitti ve sonuçta Buryat şamanizmi ortaya çıktı. O zamanlar savaşlar vardı ve Şamanizmin en şiddetli yönü, yani koruyuculuğu ön plana çıktı. Geri kalanı o anda talep edilmedi, bu yüzden şamanlar unutuldular ve sonuç olarak Buryat Şamanizmi şu anda var olduğu formda ortaya çıktı. Bazen buna - savaş Şamanizmi 
de denir. Her millet, kendi Şamanizm yönünü kurmuştur. Sonuç olarak, ayrı bir Afrikalı, ayrı bir Meksikalı, ayrı bir Perulu Şamanizmi ortaya çıktı. Carlos Castaneda kitaplarında Kızılderili Şamanizminin atalarının Sibiryalı olduğunu yazdı. Bir noktada gerçek Şamanlık yok olup gitti. Ancak Sibirya'nın ruhu, bilgiyi aktaracakları adayı yeniden buldu. Şimdi her şey yolundadır. Hangi ülkeye, hangi kitaya gidersem gideyim - Brezilya, Meksika, Avustralya, Afrika - yerel şamanlarla tanıştığımda birbirimizi anlıyoruz, çünkü her unsur benim tarafimdan biliniyor (Громова, 2018).

Modifikasyona uğramış Türk şamanlarının ve neo-şamanların uygulamalarının başında:

- Birinin talimatına göre Şamanik yeteneklere sahip olmak gelir. Örneğin, erken çocukluktan itibaren şu anda Neo-şamanlık yapan Feodora İnnokentiyevna (Dora) Kobyakova'nın (ana taraftan dedesi büyük şamanmış) "vücudunun açılmasına" şahit olduğu ortaya çıktı. Bu ise ona kuşların ve hayvanların konuşmalarını duyma, ruhların astral dünyasını görme ve onlarla iletişim kurma yeteneğini verdi.

- Özel olarak "halk şifası" Yakutya Geleneksel Tıp Derneği’nin ve şifa kurslarının bitiminden sonra ortaya çıkan neo-şamanlarla izlenildi.

Tabii ki Şamanlığın canlanmasıyla birlikte, Şamanlık geleneklerinde ciddi dönüşümlerin yaşanması az ya da çok derecede kaçınılmazdır (Колодезникова, 2011: 12).

Bügün Yakutya'da, Şamanlığın özellikle geleneksel tıp alanında ve değişik ritüel eylem biçimlerinde olmak üzere, çeşitli tezahür varyantlarında yeniden canlanması süreci tamamlanmak üzeredir. Buna Şamanlığın yeniden canlanması veya Neo-şamanlık da demek mümkündür. Geleneksel kültürün, Şamanlık da dahil olmak üzere canlandırılması için Sibirya Türk halkları arasında bir çok girişimlerde bulunulur. Ancak bu süreçte Şamanlığın, yerli halkların yaşamındaki rolü bir çok hâlde gereksiz yere abartılır. Tümüyle alternatif tıp, tedavi şekilleri, büyü, magik uygulamalar bir çokları tarafından din adlandırılan Şamanlığa mal edilir. Destan anlatıcılarını, halk sanatçılarını yok sayarak şamanları eski kültürün hem yaratıcısı hem de koruyucusu adlandıranlar da vardır. Bütün bu olumsuz "yeniliklere" bakmayarak Sibirya Türklerinin geleneksel Şamanlı̆̆g ihya etmek çabaları takdire şayandır.

Ancak tarihî gerçeklik Neo-şamanlığın, geleneksel Şamanlığın bu veya diğer şekilde deformasyon süreci üzerinde inşa edildiğini inkâr edilemez şekilde ortaya koymaktadır. Nitekim Sibirya'nın bir çok bölgesinde şaman adaylarının deneyim kazanabilecek geleneksel Şamanlığın yokluğu, şaman ritüellerinin geçirilmemesi, tek kelimeyle Şamanlıkla ilgili arka plan bilgisinin ortadan kalkması, geleneğin yıkılmasındaki en güçlü faktörlerden biri oldu. Ve neo-şamanların bazıları şaman olmak için kendi kendine çalışmak zorunda 
kaldılar. Aynı zamanda geleneksel toplumlardaki Şamanlık da dönüşmeye ve düzleşmeye başladığı için eğitim ve öğretim süreçlerinde de bir çok değişmeler söz konusu oldu. Bu varsayım Şamanlığın tamamen kaybolmadığı Tuva'da, Yakutya'da, Altaylı kavimlerde farklı bir süreçle eş anlamlı olgu sergiledi. Yani adları zikredilen Türk bölgelerinde Neo-şamanlık geleneksel unsurların restore edilmesi formunda ortaya çıktı ki buna genel anlamıyla Şamanlığın modifikasyonu demek daha doğru olacaktır.

Özetle Sibirya Türk Şamanlığı hem 1) geleneği yeniden dirçeltmek, 2) hem de geleneksel Şamanlıktan bir şeylerin kalmadığı bölgelerde (Mesela, Hakasya'da, Şorya'da) yenisini oluşturmakla karakterize edilir.

XX. yüzyılın sonu XXI. yüzyılın başlarında Yakutya Neo-şamanizminin karakteristik bir özelliği Şamanik gösteriydi. Neo-şamanın belirli bir psikofizyolojik duruma girmede ve yardımcı ruhlara dönmede istifade ettiği metot "teatral" ritüeldir. Bu teatral gösterinin içeriği yeni olup şaman tarafından parasal bir ödül için gerçekleştirilir, örneğin evde, idari yerlerde temizlik ritüeli vb. gibi olayları göstermek olur.

Onu da kaydetmekte yarar vardır ki Neo-şamanlıkla yanaşı geleneksel Şamanlık konusunda direnen, onu yaşatmaya çalışan Yakut şamanları da vardır. Bunlar Yakut Şamanlığını araştıranların yekdil fikrine göre geleneği doğrudan korumakla yükümlü Evenk asıllı Yakut şamanı Savey Vasilyev ve Yakut F. F. İvanov ve diğerleridir ki başarılı ve aktif bir uygulamaya öncülük ediyorlar.

Türk neo-şamanlarının bir modifikasyon özelliği de onların bazı sosyal görevler almasıyla alakalıdır. Hatta Sibirya'nın bazı bölgelerinde, üniversitelerde ders veren, vekil olan, devlet organlarında, toplumsal işlerde görev alan şamanlar da vardır. Ancak bu insanlar kendilerini bilen kişi adlandırırlar ve Şamanlık yapsalar da şamanlardan farklı olduklarını dikkate çattırırlar.

Yakutların, Hakasların, Tuvalıların, Altaylıların arasında yaranan şaman dernek ve tedavi merkezleri de çoğu kez tedavi seansları, arındırma ritüelleri yapmakla, geleceğe bağlı bazı tespitlerde bulunma eylemi gerçekleştirmekle tanınıyorlar. Bunu yeni yaranan Şamanlığı yaşatma adına kurulan örgütlerin varlığı da göstermektedir. Nitekim Hakasya'da "Ak çayan", "Han-Tigir" gibi şaman dernekleri, Tuva'da "Düngür" adlı dernek, "Adıg Eeren" adlı şaman merkezi (2017 verilerine göre Tuva'da 7 şaman merkezi var), Yakutya'da "Kut-sür", "Ayı1 balagana" gibi şaman örgütleri veya şaman toplulukları kurulmuştur. Bundan başka Buryatlar arasında "Baykal", "Tengeri" gibi dernekler, "Deeje" adlı bir dinî örgüt, "Bo-Darhan" ve "Lusad" gibi kurumların büyük çoğunluğu genelde XXI. yüzyılda kurulmuştur.

Modifikasyona uğrayan Sibirya Türk Şamanlığı biraz siyasileşmiş, biraz finans sektörüne girmiş, bir az etnoturizmle uğraşan, bazı devlet idarelerinde görev alan insanlardan oluşmaktadır. Zaten şaman merkezlerinin yaranması 
kendi başına millî, kültürel, sosyal dirçelişin neo-şamanlarsız ötüşemeyeceği sinyallerini vermektedir. Bundan başka neo-şamanlar siyasi olaylara da aktif tepki vermektedirler. Nitekim Nikolay Oorjak yönetiminde "13 Şamanın Çağrısı" adlı Uluslararası Etnik Festivali her y1l Tuva'da düzenleniyor. 2014 y1lında bu etkinliğin amacı "Savaşın eşiğinde insanlığın geleceği ile ilgili Göklerin iradesini istemek" idi.

2018 yılında festivale Ekvador, Meksika, Peru, Moğolistan, Tuva, Hakasya ve Yakutya'dan şamanlar katıldı. Festivalin organizatörü Nikolay Oorjak, boğazda şarkı söyleme ustası, müzisyen, halk şifacısı, Kara Gökler klanından kalıtsal Tuvalı şaman, Geleneksel Tıp Derneği Sorumlu Üyesi, manevi ve sağlı̆̆ iyileștirme sistemi (Un-Kun (Güneşin sesi) kurucusu olarak bilinen birisidir. Festivalin 2019 hedefleri "Toprak Ana'nın arındırılması, genel refah ve kalkınma" olarak ilan edildi. 2020 yılı 25 Haziran'dan 30 Haziran'a kadar, Büyük Kozmik Döngü sırasında, gezegenin en güçlü 13 şamanı, çok günlük Şamanik gizemler sırasında dokuz dünyanın ruhunu çağıracak olan dünyamızın merkezinde toplanacak. Ortak manevi uygulamalar Toprak Ana'yı, evrensel refahı ve gelişimi, temizliği amaçlamaktadır ("Зов 13 шаманов”).

Aynı ile Hakasya'da da düzenli olarak her yıl (bir kez de 2015'te Novosibirsk’te) Tuva, Altay, Hakasya, Novosibirsk bölgesi şamanlarının katıldı̆̆ "Tüm canlıların yararına" Hayırsever Şaman Gizemi düzenleniyor. 2019'da Abakan'daki gizemin organizatörü, "Tengri-Üger" derneğinin başkanı Svetlana Butusova idi. Buryatların "Tengeri", Sibirya halkları temsilcilerinin, ABD, Almanya, Çin ve Moğolistan'dan yabancı konukların katıldığı Olhon Adası'nda (Baykal Gölü) her yıl uluslararası bilimsel ve pratik konferanslar düzenlemektedir. 2002'de Olhon'da uluslararası konferans, toplu bir ritüel olan "Barış, iyilik ve sevgi için" adı altındaki organizasyonla sona erdi (Елинская, 2020: 79-80). Dünyanın, insanlığın kaderiyle ilgili bu tür organizasyonların düzenlenmesi Neo-şamanlığın toplumsal hayatta aktif rolünden haber verir.

\section{Sonuç veya Bir Soruya İki Cevap}

Sibirya Türk Şamanlığı tarihinin en eski çağlarından bugüne değin bir soruya iki cevap vermekle özdeştir: 1) Şaman olunur sorusuna geleneksel Şamanlığın cevabı; şaman olunmaz, şaman olarak doğulur, şeklindedir. 2) XXI. yüzyıl neo-şamanının bu soruya cevabı ise; şaman olunur türündendir. Birinci cevapta şaman olunmaz, çünkü bu bir seçilmişliktir, vergidir, eğitimle, istekle bağlı değildir, kuralı yatar. İkinci cevapta şaman olunur, çünkü bu isteğe bağlıdır, kendini geliştirmekle, gerekli alt yapıyı hazırlamakla, deneyimlerle mümkündür. Bir sorunun iki cevabından çıkarılan sonuca göre, Şamanlık kutsallıktan, gizlilikten, sırlı olmaktan çıkarak sekülerleşmiş, ortada sır adına bir 
şey kalmamıştır. Şamanlık ezoteriklikten egzoterikliğe geçmiştir ve yeni dünyanın yeni şamanı ortaya çıkmıştır. Ancak bizim bildiğimiz sırlar hâlen de Şamanlığın iç dünyasını açmaktan çok uzaktır.

Ve sonda tıpkı Batı dünyasında olduğu gibi Sayan-Altay ve Yakut neo-şamanı genellikle daha yüksek bir eğitime sahiptir, bazıları tıbbi, bazıları psikoloji sahasında eğitim görmüş, Şamanlık hakkında okumuş, hatta Budizm, Hristiyanlık, İslam gibi dünya dinleri ile tanışmış, modern bilimsel teorilerin temellerine aşina insanlardır. Şamanlığın ruhunu içten, geleneksel kültürden alıp onu, farklı unsurları barındıran eylem ve metotlarla zenginleştirmekle yeni bir çağ başlattıkları kuşkusuzdur. Buna "temel Şamanlık" veya "Neo-şamanlık" veya "Şamanlığın yeniden canlandırılması" denilmesinin hiçbir farkı yoktur. Asıl olan Şamanlığın kendini hem iç dinamikleri hem de dış etmenleri sayesinde yenilemesidir. Neo-şamanların sayesinde bugün Şamanlığın hemen hemen gizli-saklı bir yanı kalmamış, sır gibi tutulan kamlık ritüeli, ayin sırasındaki teknikleri, tedavi yöntemi, kozmik seyahati, ruhlarla iletişimi, transa geçmesi - bir sözle her şey açılıp gösterilmiştir (Сарангэрэл, 2003; Федоров, 2003).

XXI. yüzyıla gelindiğinde bütün dünyada Sibirya Türk Şamanlığına ilgi o kadar artmıştır ki bir çok bilim adamları Sibirya'dan göç eden neo-şamanlara büyük merkezler, tedavi kurumları açmış, kendileri de defalarla Sibirya'ya seyahat etmiş, yerli halkın şaman ve halk hekimliği geleneğini öğrenmeğe çalışmışlardır. Özellikle belirtmek gerekir ki Batı dünyasının M. Harner metodlu Neo-şamanlığı, Sibirya için fazla bir değere sahip değildir ve Türk Şamanlığ bir dirçelme, canlanma, yeniden kurulma temelinde Neo-şamanlığın doğuş sancılarını çeker. Küreselleşen Şamanlığa Sibirya Türk Şamanlığının katkısı (seminer, konferans, çalışma vs. formunda) inkâr edilemez. Ve nihayet bugüne kadar şamanın ne olduğu ve olmadığ 1 ya da içinde gelişmekte olduğu ortamı neyin oluşturduğuna dair tutarlı bilgimiz olmadığı hâlde bir de ortaya Neoşamanlık adı altında bir dizi kompleks magiko-deneyimsel özelliğe sahip olgu çıktığını da dikkate almalıyız.

Tüm verilere dayanarak Sibirya ve Orta Asya Türk Neo-şamanlığını 3 grup altında toparlamak mümkündür:

1. Geleneksel Şamanlığın varisi rolünde Neo-şamanlığı yaşatanlar. Buraya Tuva ve kısmen Altay Türk şamanlarını ait etmek olur. Nitekim bu bölgenin şamanları genelde kendilerinin ata şaman ruhundan vergi aldıklarını belirtirler.

2. Geleneksel Şamanlığı canlandırmak yoluyla kendilerini soyla geçen şamanlar adlandıran, ancak usta şamanlardan Şamanik teknikleri öğrenenler ki buraya Yakut şamanları, şartlı olarak Hakas, Şor şamanları dahildir. Bu iki sonuncuları geleneksel şamanlığın yok olma eşiğine geldiği ve Şamanik uygula- 
maları bilen büyük şamanların kalmadığı toplulukta ortaya çıkan Neo-şamanlık adlandırmak mümkündür. Hatta bazı Hakas şamanlarının şamanik teknikleri öğrenmek için Tuva şaman merkezlerine, Altaylı şamanlara baş vurdukları da bilinmektedir.

3. Hem İslam'ın hem de ateist propagandanın güçlü olduğu Orta Asya bakşıları 1990'ların başından itibaren Müslümanlıkla Şamanik uygulamaların iç içe olduğu, karma bir şaman geleneği inşa etmişlerdir.

\section{KAYNAKÇA}

Bayat Fuzuli (2006). Ana Hatlarıly Türk Şamanlığı. İstanbul: Ötüken Ötüken

Bayat Fuzuli (2019). Türk Şaman Metinleri. Efsaneler ve Memoratlar. 3. Basım, İstanbul:

Алексеев Николай Алексеевич (1975). Традииионные Религиозные Верования Якутов в $X I X$-начале $X X$ в. Новосибирск: Наука

Алексеев Николай Алексеевич (1984). Шаманизм Тюркоязычных Народов Сибири. Новосибирск: Наука

Анохин Андрей Викторович (1924). Материальг по Шаманству у Алтайцев, Собранные во Время Путешествий по Алтаю В 1910-1912 Гг. По Поручению Русского Комитета Для Изучения Средней и Восточной Азии. Сб. МАЭ. Л., Т. 4, вып. 2

Арбачаков Александр Никитич (2004). Шаманы Горной Шории: Этнографические Очерки и Тексты Камланий. Новокузнецк: Кузнецкая крепость

Басилов Владимир Николаевич (1984). Избранники Духов. Moskва: Политиздат

Басилов Владимир Николаевич (1992). Шаманство у Народов Средней Азии и Казахстана. Москва: Наука

Басилов Владимир Николаевич, Кармышева Б.Х. (1997). Ислам у Казахов (до 1917 г.). Москва: Наука

Баскаков Николай Александрович (1973). “Душа в Древних Верованиях Тюрков Алтая: (Термины, Их Значение и Этимология)”, Советская Этнография. № 5, s.108-113 Батъянова Елена Петровна (1999). "Представления Телеутов о Природе Шаманского Дара", Материаль Международного Конгресса “Шаманизм...”. Ч. 1. s.309-323

Батъянова Елена Петровна (2005). "К Портретам Сибирских Шаманов", ПИ ИЭА PAH. 2003. Мосkва, s.150-164

Бутанаев Виктор Яковлевич (2006). Традиционный Шаманизм Хонгорая. Абакан: Хакасского государственного университета им. Н.Ф.Катанова

Вайнштейн Севьян Израилевич (1961). Тувинџы-Тоджинџы. ИсторикоЭтнографические Очерки. Москва: Издательство Восточной Литературы

Вербицкий Василий Иванович (1893). Алтайские инородцы: Сборник этнографических статей и исследований алтайского миссионера, протоиерея В. И. Вербицкого. Москва: Т-во скоропечатни А.А.Левенсон

Горшунова Ольга Вениаминовна (2001). "Образы Духов-Покровителей Среднеазиатских Шаманов (Бахши): К Вопросу о Психоментальном Аспекте в Этнографическом Исследовании", Материаль Международного Интердисциплинарного Научно-Практического Симпозиума «Экология и Традиционые Религиозно-Магические Знания» Москва-Абакан - Кыззыл 9-21 Июля 2001 Г. Этнологические Исследования по Шаманствуи Иным Традииионным Верованиям и Практикам, Т.7, Часть 2. Москва: Институт Этнологии и Антропологии Российская Академия Наук, s.22-33 
Громова Алла (2018). Сибирская Шаманка. Вам Поможет Сила Рода. Москва: ООО Издательство АСТ, https://www.litres.ru/alla-gromova/sibirskaya-shamanka-vam-pomozhetsila-roda/chitat-onlayn/ (Erişim tarihi 03.06.2020)

Диваев Абубакир (1902). “Киргизские болезни и способы их лечения”, Туркестанские Ведомости № 80

Дыренкова Надежда Петровна (1949). “Материалы по Шаманству у Телеутов”, Сборник Музея Антропологии и Этнографии Акад. Наук СССР. Т.10. s.108-190

Дыренкова, Надежда Петровна (1930). "Получение Шаманского Дара по Воззрениям Турецких Племен”, Сборник Музея Антропологии и Этнографии Акад. Наук СССР. Вып. 9. - s.261-291

Доронин Дмитрий Юрьевич (2013). “Политик? Лекарь? Шаман? Современные Шаманы Алтая", Эпическое Наследие и Духовные Практики в Прошлом и Настоящем. Этнологические Исследования по Шаманству и Иным Традиџионным Верованиям и Практикам. Т.15, ч.1. Москва: Российская Академия Наук Институт Этнологии и Антропологии имени Н.Н.Миклухо-Маклая, s.85-101

Доронин Дмитрий Юрьевич (2013). “Политик? Лекарь? Шаман? Современные Шаманы Алтая", Эпическое Наследие и Духовные Практики в Прошлом и Настоящем. Этнологические Исследования по Шаманству и Иным Традиционнылм Верованиям и Практикам. Т.15, ч.1. Москва: Российская Академия Наук Институт Этнологии и Антропологии имени Н.Н.Миклухо-Маклая, s.85-101

Елинская Янина Алексеевна (2020). Культурные Практики Неошаманизма Сибири И Дальнего Востока России: Коммуникативный И Аксиологический Аспекты. Диссертация на соискание ученой степени кандидата культурологии. Комсомольск-на-Амуре

“Зов 13 шаманов”. http://13shamans.com/ (Erișim tarihi 05.08.2020)

Иванов Сергей Васильевич (1954). Материаль по Изобразительному Искусству Народов Севера. Москва-Ленинград: Изд-во АН СССР

Кении-Лопсан Монгуш Борахович (1987). Обрядовая Практика и Фольклор Тувинского Шаманства. Конеч ХІХ нач. ХХ века. Новосибирск: Наука

Кенин-Лопсан Монгуш Борахович (1999). Тувинские Шаманы. Mockва: Macka;

Колодезникова Любовь Дмитриевна (2011). “Возрождение Шаманизма На Стыке Веков”, Научный Журнал КубГАУ, №73(09), s.613-627

Ксенофонтов Гавриил Васильевич (1930). Легенды и Рассказы о Шаманах: У Якутов, Бурят и Тунгусов. Москва: Безбожник

Ксенофонтов Гавриил Васильевич (1992). Шаманизм. Избранные Труды. Якутск: Творческо-производственная фирма Север-Юг

Непомнящих Наталья Алексеевна (2016). “Сюжеты о Шаманах в Литературах Народов Сибири: К Постановке Проблемы”, Северо Восточный гуманитарный вестник. № 2(15), s.76-80

Непомнящих Наталья Алексеевна (2019). “Литература и вопросы этнокультурной идентичности: тема шаманизма и сюжеты о шаманах в творчестве писателей Сибири”, Сибирский филологический журнал. № 4, s.180-186 Наука

Новик Елена Сергеевна (1984). Обряд и фольклор в сибирском шаманизме. Мосkва:

Попов Андрей Александрович (1947). “Получение “Шаманского Дара” У Вилюйских Якутов”, Трудь Института Этнографии, 1947, s.282-293

Попов Андрей Александрович (2008). Камлания Шаманов Бывшего Вилюйского Округа. Новосибирск: Наука

Потапов Леонид Павлович (1991). Алтайский Шаманизм. Ленинград: Наука 


\section{Prof. Dr. FUZULİ BAYAT}

Ревуненкова Елена Владимировна (2012). "Владимир Николаевич Басилов и современные исследования шаманства”, «Избранники Духов» - «Избравшие Духов»: Традииионное Шаманство и Неошаманизм. Памяти В.Н. Басилова (1937-1998). Сборник Статей. Изд. 2-Е, Перераб. и Доп. Этнологические Исследования По Шаманству И Иньым Традиционнылм Верованиям И Практикам. Т. 17, Москва: Институт этнологии и антропологии Российская академия наук, s.31-42

Сагалаев Андрей Маркович (1984). Мифология и Верования Алтайчев. ЦентральноАзиатские Влияния. Новосибирск: Наука

Самдан Зоя Баировна (2019). “Модификация архетипического образа тувинского шамана в творчестве М. Б. Кенин-Лопсана" [Электронный ресурс] Новые исследования Tyвbl. № 3, https://nit.tuva.asia/nit/article/view/872 (Erișim tarihi 25.10.2019)

Сарангэрэл Гарькавый Александр Д. (2003). Зов Шамана: Древние Традичии и Духовные Практики. Мосkва: Фаир-Пресс, Гранд

Сатлаев Феофан Александрович (1974). Кумандинџы (Историко-этнографический очерк XIX - первой четверти XX века). Горно-Алтайск: Горно-Алтайское отделение Алтайского книжного изд-ва

Сыченко Галина Борисовна (2000). "Ульгень, Тьажин, Кыргыс и другие ... (заметки о чалканском шаманстве)", Челканцы в исследованиях и материалах XX века. Mосkва, s.114-127

Сыченко Галина Борисовна (2002). “Корреляция вербальной и музыкальной структур шорского шаманского текста”, Гуманитарные науки в Сибири. № 4. s.69-65

Сыченко Галина Борисовна (2004). "Поэтика и структура чалканского шаманского текста”, Языки коренных народов Сибири. Новосибирск. Вып. 15: Чалканский сборник. s. $73-101$

Трощанский Василий Филиппович (1903). Эволюция чёрной веры (шаманства) у якутов. Казань: Типо-литогр. императ. ун-та, 1903

Тюхтенева Светлана Петровна (2004). “Современные Представления о Сакральном у Алтайцев”, Сакральное в Традичионой Культуре: Методология Исследования, Методьь Фиксачии и Обработки Полевых, Лабораторных, Экспериментальных Материалов. Материалы Международного Интердисчиплинарного Научно-Практического Семинара-Конференции. Москва - Республика Алтай: 6-15 июля 2003 г. Мосkва: ИЭА PAH, s.265-269

Федоров Владимир (2003). Тайны Вуду и Шаманизма. Во Власти Потусторонних Сил. Москва: Вече

Функ Дмитрий Анатольевич (1997). Телеутское Шаманство: Траидиионные Этнографические Интерпретации и Новые Исследовательские Возможности. М.: РАН Институт Этнологии и Антропологии им. Н.Н. Миклухо-Маклая

Харитонова Валентина Ивановна (2003). “Шаманы Без Бубнов”, ВK. № 3(14). s.130140

Харитонова Валентина Ивановна (2006). Феникс из Пепла? Сибирский Шаманизм на Рубеже Тысячелетий. Москва: Наука

Харитонова Валентина об Исследованиях Майкла Харнера, Народном Целительстве и Городских НІаманах, https://postnauka.ru/video/48994 (Erișim tarihi 05.09.2019)

Хомушку Ольга Матпаевна (1998). Религия в истории культуры тувинцев. Мосkва: Наука

Шаманизм народов Сибири (2006). Этнографические материалы XVIII-XIX вв.: Хрестоматия. Составивел. Т.Ю.Сем; СПб.: Филолог, фак. СПб. гос. ун-та. 


\section{AKRA KÜLTÜR SANAT VE EDEBIYYAT DERGİSİ 2021 (S.24) c.9 / s.9-41}

Ярлыкапов Ахмет Аминович (2012). “Феномен Йинли Молла в Духовной Культуре Ногайцев”, «Избранники Духов» - «Избравшие Духов»: Традичионное Шаманство и Неошаманизм. Памяти В.Н. Басилова (1937-1998). Сборник Статей. Изд. 2-Е, Перераб. и Доп. Этнологические Исследования по Шаманству и Иным Традиџионным Верованиям и Практикам. Т. 17, Москва: Институт Этнологии и Антропологии Российской Академии Наук, s.331-340

\section{İnternet Kaynakları}

http://pnbglaz.narod.ru/psakha/kondakov.html (Erişim tarihi 23.12.2019)

https://360tv.ru/news/tekst/shaman-king/ (Erişim tarihi 04.08.2020)

https://inosmi.ru/social/20160805/237451383.html (Erișim tarihi 07.11.2019)

https://magicbom.ru/things/shamany-altaya-i-drugih-regionov-sibiri-nastoyashchie-shamany.html (Erişim tarihi 26.02.2020)

https://nazaccent.ru/content/29870-pervyj-v-rossii-shamanskij-hram-otkroetsya.html (14.07.2020)

https://postnauka.ru/video/48994 (Erişim tarihi 08.02.2020)

https://russian7.ru/post/za-chto-v-sssr-khoteli-unichtozhit-shamano/ (Erișim tarihi 20.07. 2020)

https://ulan-ude.sm.news/pervyj-v-rossii-shamanskij-xram-chto-eto-znachit-

4704/(14.07.2020)

https://www.culture.ru/objects/452/obryad-ochisheniya-shorskoi-shamanki-a-o-kuspeko voi (Erişim tarihi 23.12.2019) 